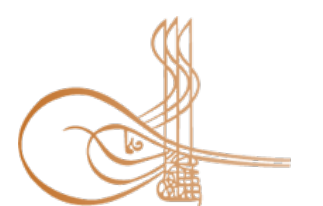

www.turkishstudies.net/social
Turkish Studies - Social Sciences

eISSN: 2667-5617

Research Article / Araştırma Makalesi

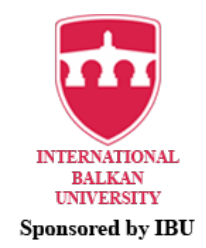

Sponsored by IBU

\title{
Kilis Kent Nüfusunun Coğrafi Analizi
}

Geographical Analysis of Kilis City Population

\author{
Ömer Faruk İncili*
}

\begin{abstract}
The town of Kilis, Turkey-Syria border and situated between the Mediterranean and Southeastern Anatolia Region is spread over approximately $16 \mathrm{~km}^{2}$. Kilis Merkez District is 205th among 973 districts and 75th among 81 city centers. According to the Socio-Economic Development Index prepared in 2004, Kilis is in the third group in terms of development among the districts divided into 6 groups. The city of Kilis is a settlement center dating back to old times. Kilis was a small town until the Ottoman domination after the Mercidabik War (1516); It developed under the Ottoman domination and assumed the function of the city. This development constitutes the first breaking point in the change of urban population. The city of Kilis continued to function as an important population center with the advantage of its proximity to Aleppo under Ottoman rule. Second break point of the urban population with the establishment of the Republic of Turkey in the determination of the Turkey-Syria border is blocked Aleppo and Kilis connection. The third development in urban development took place in 1995 when Kilis achieved provincial status. The majority of the data used in the study was obtained from TÜIK. In the 1927-2019 period, the population change of the city was analyzed by reaching the population, education, economy, housing and household numbers obtained from the general censuses and ABPRS results. In addition, population analysis from Aleppo Provincial Yearbooks and other sources were also available for the situation analysis before 1927. In the period of $1927-$ 2019, the main factor affecting the city's population change was trade (border trade). During the period when the border trade was released, the population growth rate increased. Being a border city affects the population holding capacity. The security problems experienced during the Syrian civil war are the disadvantages of being a border city. The refugee population, which is as much as the local population, has been an important factor in urbanization and urbanization.
\end{abstract}

Structured Abstract: In population geography studies, the analysis of geographical factors in distribution, composition, mobility and development of the population is important. The geographical characteristics of a place affect its population holding capacity. These qualities can be physical (natural) factors or human factors. The city of Kilis, which has a study area, is a border city. Both the Turkey-Syria border is located in the Southeastern Anatolia Region of the Mediterranean coast.

In the study, basic demographic changes of Kilis city population and the factors affecting these changes were analyzed from a geographical perspective. The data of the study was obtained by synthesizing the basic demographic components together with official statistics and field observations on an urban scale.

\footnotetext{
* Dr. Öğr. Üyesi, Kilis 7 Aralık Üniversitesi, Muallim Rıfat Eğitim Fakültesi, Türkçe ve Sosyal Bilimler Eğitimi Bölümü Asst.Prof. Dr., Kurum adının Ingilizcesi, Kilis 7 Aralı University, Muallim Rlfat Education Faculty, Department of Turkish and Social Sciences Education ORCID 0000-0002-0698-8801

ofarukincili@kilis.edu.tr

Cite as/ Atıf: İncili, Ö. F. (2020). Kilis kent nüfusunun coğrafi analizi. Turkish Studies - Social, 15(4), 1957-1983.

https://dx.doi.org/10.29228/TurkishStudies.43422

Received/Geliş: 06 May/Mayıs 2020

Accepted/Kabul: 20 June/Haziran 2020

Copyright (C) INTAC LTD, Turkey

Checked by plagiarism software

Published/Yayın: 25 June/Haziran 2020

CC BY-NC 4.0
} 
The data and findings obtained were presented in an organized way by transforming them into tables, graphics and thematic maps. These findings obtained from the raw data are associated with the place and geographical explanations are made. The socio-economic aspects of the city were evaluated by using data on distribution by age groups, fertility, rough birth, rough death, natural population growth, marriage and divorce. In addition, population projections were created for the city of Kilis, which was prepared with different methods, and population predictions were made for the future. Since the population has a very variable structure, the studies should be renewed at certain times. The fact that the population studies related to the city of Kilis have not been handled scientifically has encouraged such a study.

Kilis is a city that has continued its development by undertaking a commercial function in the population process. The change in this function in time caused the change of the city population. In terms of population development, the city can be divided into periods that show different characters. These periods are:

-1516-1920 Pre-Republic Period (Ottoman Domination Period)

- Period between 1920-1950 (Stable Increase Period)

- Period between 1950-1980 (Dynamic Increase Period)

- Post 1980 period (Second Stationary Increase Period)

The functional properties of the cities are an important factor influencing the population carrying capacity and demographic structure. In the development and population process of Kilis, human factors were at the forefront rather than physical factors. Population and development have reacted to the change in the commercial function in Kilis, an ancient city. In the period prior to the Republic because of close trade relations with Aleppo have stayed alive, but lost its function by drawing the connection Kilis Turkey-Syria border. The city, which used to be described as a "station city", lost its transportation and commercial function and started to emigrate. So much so that in 1927 the 22 largest cities in Kilis, Turkey census 1950 census declined in 42 of the queue. In the 1960s and 1970s, the reappearance of the commercial function (border trade) caused mobility in the city. Another important development in the city was the city of Kilis with the transition to provincial status in 1995. This development in administrative function caused a certain increase in population in the city. Since 2011, with the refugee population fleeing from the Syrian civil war, population accumulation occurred in the city. Although there has been a positive movement in the population growth rate in recent years, this development is influenced by the increasing temporary public officials in the city.

The evolution of the neighborhoods is also important in urban population and spatial growth. The city has developed as a result of growth in the area and population of the outskirts. Therefore, when the population of the city is taken into consideration in the scale of the neighborhoods, it is seen that the outer neighborhoods (such as Ekrem Çetin, Mehmet Sanlı, Atatürk, Kazım Karabekir. Mehmet Rıfat Kazancıŏglu, Yaşar Aktürk) are both large in terms of area and high in population. It is also understood from the data that the socio-economic level in these neighborhoods is higher than the interior neighborhoods. The inner neighborhoods in the city center (such as Şıhlar, Bölük, Abdioymağı, Mıhali, Şıh Ahmet, Büyükkütah, Innaplikütah) are small areas and less populated. The urban population tends to migrate from the inner quarters to the outer quarters. The old structure in the city center, the narrow street tradition and the settlement of the Syrian refugee population in the inner neighborhoods (low rental rates) encouraged the migration of the local population of Kilis to the outer neighborhoods.

Although the city of Kilis was the center of provincial administrative status in 1995, today it is a medium-sized city with a population of 103,883 people, and has been displaying stable population development for many years. The reason for this stagnation is:

- Kilis is a city that has largely lost its transportation function. It can only provide domestic connection with Gaziantep. Therefore, it is an isolated city due to its location. The fact that the Öncüpınar border gate was closed from time to time for political reasons affected the transportation function. The Gaziantep-İskenderun port road, which is also among the projects for the transportation function, will be an important development.

- Inadequate economic activity causes the population holding capacity to be low. The city has a service-oriented structure. Although it is an Organized Industrial Zone, sufficient production capacity has not 
been reached. However, with the realization of the project, Polateli Organized Industrial Zone, the city's population holding capacity may increase.

- Due to the fact that Kilis is weak in terms of being a central place and the impact area is narrow, its effect is limited in settlements that are administratively connected. The presence of Gaziantep with a large city and high impact area has narrowed the Kilis impact area.

- As a result of the asylum-seeker population coming from 2011 creating cheap labor force in the city, the local population tends to migrate to other cities. However, this effect cannot be seen in the data due to the increasing number of public officials in Kilis. In the field research, it was found out that migration was given and the tendency to migrate increased.

- Kilis is a city that experienced significant security problems in 2016 due to rocket attacks. This security problem has increased the trend of immigration from the city.

The city of Kilis is a settlement that has achieved significant urban growth with the influence of the refugee population in recent years. A mobility has begun in newly established neighborhoods, especially from the inner neighborhoods of the city. While the refugee population is concentrated in the inner quarters, the local population is in the outer quarters. Due to the increasing need for housing, the construction sector in the city has been revived in recent years.

Urban sprawl is developing towards northwest, west and east direction. University, hospital and Kilis-Gaziantep highway were effective in this development. It is estimated that the new state hospital will initiate new construction in the northeast of the city. The development of the city towards the south leads to criticism. The availability of fertile agricultural lands (pistachio, olive grove and vineyard areas) slowed development towards the southern part. Therefore, the ring road is the psychological limit of the city today.

Keywords: Geography, Population Geography, Demography, Kilis Population, Spatial Use

Öz: Kilis kenti, Türkiye-Suriye sınırında ve Akdeniz-Güneydoğu Anadolu Bölgeleri arasında yer alan yaklaşık $16 \mathrm{~km}^{2}$ 'lik alana yayılmıştır. Kilis Merkez İlçesi 973 ilçe içerisinde 205., 81 il merkezi içerisinde ise 75. sırada yer almaktadır. 2004 yılında hazırlanan Sosyo-Ekonomik Gelişmiş̧lik Endeksine göre ise Kilis 6 gruba ayrılan ilçeler arasında gelişmişlik açısından 3. grupta yer almaktadır. Kilis kenti, tarihi eskilere dayanan bir yerleşme merkezidir. Mercidabık Savaşından (1516) sonra Osmanlı hâkimiyetine geçene kadar Kilis küçük bir kasaba iken; Osmanlı hâkimiyetiyle birlikte gelişerek şehir fonksiyonu üstlenmiştir. Bu gelişme kentsel nüfusun değişiminde birinci kırılma noktasını meydana getirir. Kilis kenti Osmanlı hâkimiyetinde Halep'e yakınlığının avantajıyla önemli bir nüfus merkezi olma fonksiyonunu sürdürmüștür. Kentsel nüfustaki kırılma noktalarının ikincisi Türkiye Cumhuriyetinin kurulmasıyla birlikte Türkiye-Suriye sınırının belirlenmesi ve Kilis'in Halep bağlantısının engellenmiş olmasıdır. Kentsel gelişimde üçüncü gelişim ise 1995 yılında Kilis'in il statüsüne kavuşmasıyla meydana gelmiştir. Çalışmada kullanılan verilerin büyük çoğunluğu TÜiK'ten elde edilmiştir. 1927-2019 aralı̆̆ında, genel nüfus sayımları ve ADNKS sonuçlarından elde edilen nüfus, eğitim, ekonomi, konut ve hane sayılarına ulaşarak kentin nüfus değişimi analiz edilmiştir. Ayrıca 1927 öncesindeki durum analizi için de Halep Vilayet Salnameleri ve diğer kaynaklardan nüfus verilerine de ulaşılmıştır. 1927-2019 döneminde kentin nüfus değişimini etkileyen ana faktör ticaret (sınır ticareti) olmuştur. Sınır ticaretinin serbest bırakıldığı dönemlerde nüfus artış hızında artışlar görülmüştür. Kentin bir sınır kenti olması nüfus tutma kapasitesini etkilemektedir. Suriye iç savaşı sırasında yaşadığı güvenlik problemleri ise bir sınır kenti olmanın dezavantajlarıdır. Kentte yerli nüfus kadar bulunan sığınmacı nüfus kentleşme ve kentlileşme üzerinde etkili olan önemli bir etken olmuştur.

Anahtar Kelimeler: Coğrafya, Nüfus Coğrafyası, Demografi, Kilis Nüfusu, Mekânsal Kullanım

\section{Giriş}

Nüfus coğrafyası çalışmaları; nüfusun dağılımı, bileşimi, göçü ve büyümesindeki etkili olan coğrafi faktörlerin açıklanması şeklinde gerçekleştirilir. Nüfus coğrafyası çalışmaları demografiyi içermekle birlikte mekânsal bağlamda değişen nüfus dağılımlarının özelliklerine odaklanmaktadır. Özellikle nüfusun yoğunlaşma alanları, nüfus büyüklüğü ve bileşiminin 
doğurganlık, ölüm ve göçten oluşan temel demografik süreçlerin nasıl düzenlendiği gibi hususlar dikkate alınır (Rogers, Castree ve Kitchin, 2013). Nüfusun mekânsal düzenini anlatmak için ise nüfus yoğunluk haritaları ve dağılış haritaları kullanılabilir (Ehrlich ve Anne, 1990).

Mekânsal demografinin güçlü geleneğinin üzerine inşa edilmiş olan ve gittikçe daha çeşitli nicel ve nitel metodolojileri bünyesinde barındıran nüfus coğrafyası, bugün insan hareketleri, bölgesel demografik değișkenlik ve bu nüfus süreçlerinin meydana geldiği sosyal bağlama daha bütüncül bir anlayış geliştirmenin peşinden koşmaktadır (Özgür, 2016: 3). Çünkü nüfus süreçleri ve özellikleri, bir yandan toplumları şekillendirmekte, diğer yandan da onlara karakteristik kazandırmaktadır.

Bir yerin nüfus taşıma kapasitesini belirleyen faktörler fiziki ve beşeri faktörler olmak üzere temelde ikiye ayrılabilir. Nitekim iklim, su kaynakları, bitki örtüsü, toprak verimliliği, yeryüzü şekilleri ve yükselti gibi doğal çevre faktörlerinin yanı sıra, tarihi olaylar ve idari yapı ile bizzat insan ve onun eseri olan beşeri ve ekonomik faaliyetlerin nüfusun dağılışı üzerinde önemli rol oynadığı söylenebilir (Tanoğlu, 1969 ve Doğanay, 1997). Dolayısıyla bir yerde bulunan nüfus ve o nüfusun demografik nitelikleri (dağılış, yoğunluk, kır-kent bileşimi, cinsiyet ve yaş yapısı, artış hızı, bağımlılık oranı ve göç) doğal ve beşeri coğrafya özellikleriyle değişkenlik göstermektedir.

Bütün bunlara ek olarak, bir bölgede bulunan nüfus miktarı ile nüfusun dağılışı ve yoğunluğu, cinsiyet ve yaş yapısı, kır-kent bileşimi, artış hızı, bağımlılık oranı ve göç hareketine kaynaklık etme miktarı gibi pek çok özelliği, çevrenin doğal ve beşeri coğrafya özellikleri ile bağlantılıdır.

Bir yerin nüfus taşıma kapasitesi ve potansiyelini açıklayabilmek için yerleşmenin tarihi geçmişine bakmak önemlidir. Mezopotamya, Anadolu, Kuzey Suriye ve Misır gibi en eski uygarlıkların yaşadığı coğrafyaya yakın olan Kilis'te yerleşmenin tarihinin çok eskilere gittiği söylenebilir. Yörede yer alan birçok höyük yerleşmesi de bu görüşü yansıtmaktadır. Kökten'e (1952) göre Kilis çevresinde yerleşme tarihi Alt Paleolitik'e kadar uzanmaktadır (Kökten, 1952: 198). Dolayısıyla çalışma sahasının tarihi dönemlerde de yoğun nüfuslanmış bir yöre olduğu ifade edilebilir. Kesici'ye (1992) göre Kilis şehri kuruluşundan bugüne kadar da aynı noktayı işgal etmemiştir. Eski Kilis'in bulunduğu muhtemel yerler arasında bugün şehrin bat1-güneybatısında Tarzime Han mevkii veya kentin doğusunda yer alan İlezi bahçesi söylenebilir (Kesici, 1992: 94).

Osmanlı hâkimiyetine kadar Kilis sönük kalmış bir yerleşmedir. Kilis, 1516 yılında Yavuz Sultan Selim tarafından fethedilmesiyle beraber önem kazanan bir yerleşmedir. 1519 yılında yani Mercidabık Savaşından 4 yıl sonra nüfusu 1500 civarında olup, 4 mahalleden oluşan kasaba görünümündeydi (Konyalı, 1968). 19. Yüzylla gelindiğinde Kilis önemli bir nüfus merkezi haline gelmiştir. Nitekim Halep Vilayet Salnamelerinde kent nüfusunun 20 bin kişinin üzerinde olduğu görülmektedir. 1921 yılında Türkiye-Suriye sınırı çizilene kadar Kilis, Halep'e yakınlığı sebebiyle canlı ve nüfus cazibe merkezi halindeydi. Ancak sınırla birlikte bir fonksiyon kaybına uğramıştır. Dolayısıyla nüfus artışının Cumhuriyet döneminde durağanlaşması ulaşım ve ticari fonksiyon kaybıyla izah edilebilir. Kilis'in 1995 yılında Gaziantep'e bağlı bir ilçe iken il statüsüne kavuşması ise kentsel gelişim ve nüfus tutma kapasitesi açısından önemli bir gelişme olmuştur. 


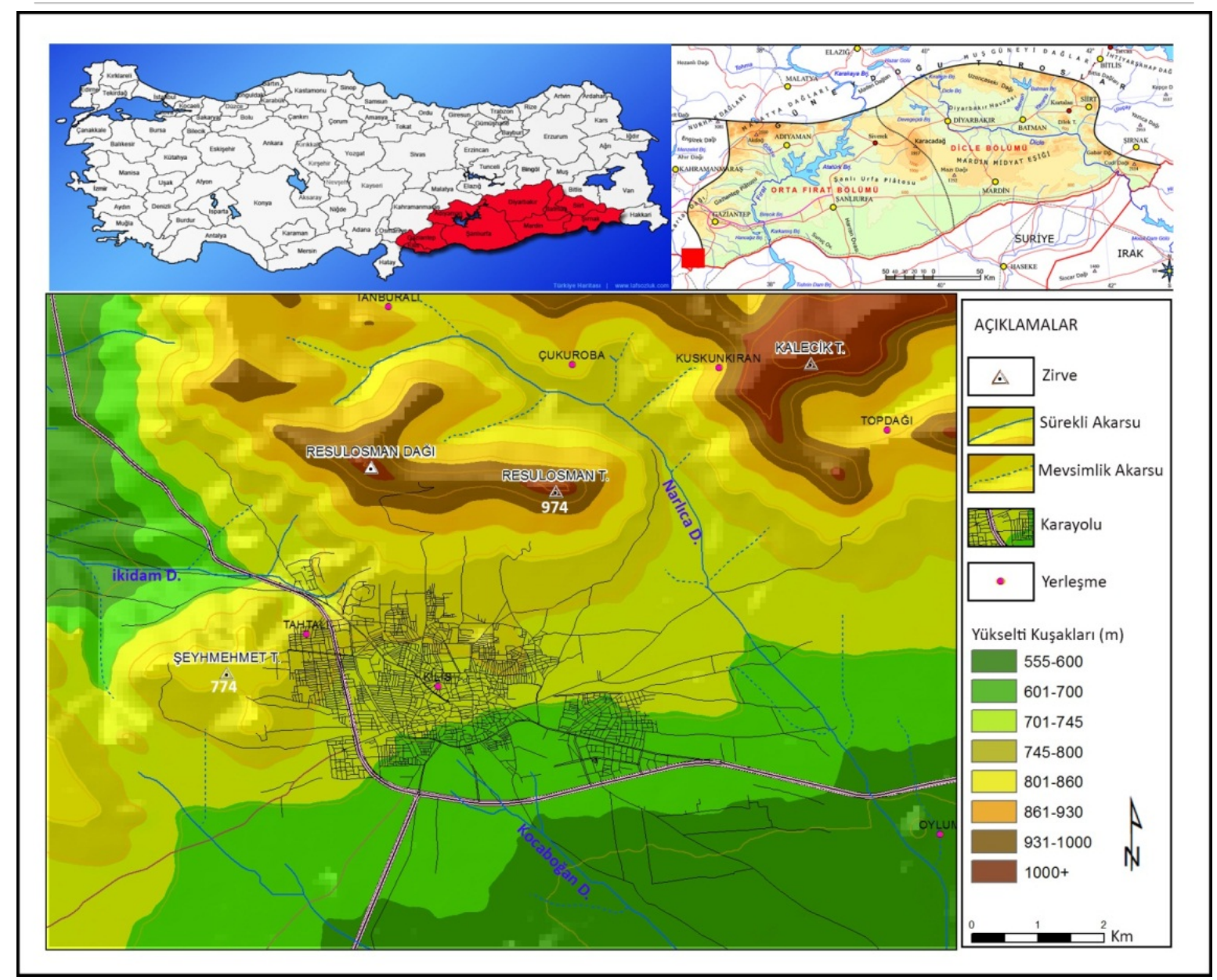

Şekil 1. Kilis Kenti Lokasyon Haritas1

Kilis kenti Gaziantep platosunun eteklerine doğru kurulmuş güneye doğru alçalan düzlük sahalar ile karakterize olur. Kentin kuzey ve batı kesimleri ise plato ve basık dağlık alanlardan oluşur. Kentin ortalama yükseltisi 650 metre olup, kuzeyindeki Acar ve Resulosman Dağı kütleleri 950-1000 metre; batısında ise 770 metre (Şeyh Mehmet Tepe) yükseltide kalker/marn karıșımı basık tepelikler yer almaktadır. Şehrin güney kısımları ise Kilis ovasının devamı niteliğinde olan, Suriye topraklarına doğru alçalan düzlüklerden meydana gelmiştir (Şekil 1).

Kilis'te kentsel yayılmayı sinırlandıran faktörler fiziki ve beşeri faktörlerdir. Kentin kuzeyinde dağlık kütlenin yer alması ve eğim derecelerinin yüksekliği sınırlandırıcı bir faktör olmuştur. Batı kesimindeki alanda yer alan tepelikler de kentsel yayılımı sınırlandırıcı doğal faktör niteliğindedir. Kentin güneyi ve doğusu ise fiziki özellikler açısından sade görünümlüdür. Ancak güney kısmında (kente $5 \mathrm{~km}$ uzaklıkta) Türkiye-Suriye sınırının uzanması kentsel yayılımı sinırlandıran beşeri faktörü meydana getirir. Kentin fiziki ve beşeri özellikleri kent formu ve dokusunu da etkilemiştir. Kilis kenti uzun yıllar düzlük topografyada dairevi formunu korurken günümüzde kuzey ve batıdaki fiziki engeller ve güneydeki sınır engeli sebebiyle dairevi form değişmiş ve doğuya doğru kentsel yayılım hızlanmıştır. Ancak kentsel büyüme son yıllarda batıdaki tepelik alanlara ve kuzeydeki dağlık sahalara doğru yayılma eğilimindedir.

Kentsel gelişim ve nüfuslanma açısından ulaşım fonksiyonu önem arz etmektedir. Kilis'in gelişimi ve nüfuslanma sürecinde ulaşım fonksiyonunun etkisi kuvvetli bir şekilde hissedilmektedir. Kilis, Cumhuriyet öncesinde Halep merkezli kervan yollarının güzergâhı olması sebebiyle (Kilis-Halep arası $60 \mathrm{~km}$ ) ticari açıdan canlı ve önemli bir nüfus toplanma alanıdır. 
Ancak Türkiye-Suriye sınırının çizilmesi Halep'e ulaşım fonksiyonunu zayıflatmış ve Kilis ulaşım fonksiyonunu kaybeden bir şehir olarak nüfus artış hızını kaybetmeye başlamıştır. Kilis kenti bugün ulaşım bağlantılarının zayıf kaldığı bir çıkmaz sokağa benzetilebilir. Doğuda standardı yüksek Kilis-Gaziantep karayolu (60 km) ile Gaziantep şehrine; batıda ise çoğunlukla tek gidiş-tek geliş yol ile Gaziantep'in İslahiye ilçesi $(80 \mathrm{~km})$ ve Antakya'ya $(145 \mathrm{~km})$ ulaşım sağlanmaktadır. Kilis'in sadece Gaziantep iline komşu olması ve sınır kenti olması ulaşımda kavşak nokta olmasını mümkün kılamamaktadır.

Türkiye'de kentleşme politikalarından çıkarılan yasalardan ve uygulamalardan hareketle merkeziyetçi yaygınlaştırma politikasını takip ettiği söylenebilir (Canpolat, 2019). Dolayısıyla kentler cazibe merkezleri haline getirilerek nüfus toplanma ve çekim merkezleri haline getirilmiştir. Kilis kenti de etki sahası sınırlıda olsa orta ölçekli kentsel fonksiyonların geliştiği merkezlerden biridir. Kentleşmeye bağlı gelişme ve büyüme de nüfus artırıcı bir etki yapmaktadır. Kilis 2013 yılı İl Gelişmişlik Endeksine göre 5. Grup iller arasında, 70. sırada yer almaktadır (Gül ve Çevik, 2015).

\section{Yöntem ve Amaç}

Çalışmada Kilis kent nüfusunun temel demografik değişimleri ile bu değişimlerde etkili olan faktörler coğrafi bakış açısıyla analiz edilmiştir. Cumhuriyet öncesi nüfus verilerine 16. Yüzyılda Tahrir Defterlerinden, 17. Yüzyılda Evliya Çelebi Seyahatnamesinden ve 19. Yüzyıl verilerine de Halep Vilayet Salnamelerinden ulaşılmıştır. Cumhuriyet sonrası nüfus verileri ise (1927-2019) TÜİK'ten elde edilmiş̧ir. Kentsel nüfusun mekânsal dağılışı için mahalle bazında nüfus dağılış verileri, eğitim, konut ve işyeri sayıları temin edilerek tablo ve grafikler oluşturulmuştur. Ham verilerden elde edilen bu bulgular mekânla ilişkilendirilerek coğrafi izahlarda bulunulmuş̧tur. Yaş gruplarına göre dağılım, doğurganlık, kaba doğum, kaba ölüm, doğal nüfus artışı, evlilik ve boşanma verileri de kullanılarak kentin sosyo-ekonomik yönleri değerlendirilmiştir. Ayrıca farklı yöntemlerle hazırlanan Kilis kenti için nüfus projeksiyonları oluşturulup, gelecek için nüfus ön görülerinde bulunulmuştur.

Çalışmada temel demografik bileşenlerin kentsel ölçekte resmi istatistik ve arazi gözlemleri ile birlikte sentezlenmesi yolu izlenmiştir. Elde edilen veri ve bulgular tablo, grafik ve tematik haritalara dönüştürülerek organize bir şekilde sunulmuştur.

Araştırmadaki sınırlılıklar ise kente yönelik göç verilerinin bulunmaması, yakın dönemlere ait bazı verilerin ise analiz için kısa bir zamanı kapsaması, kent nüfusunun iktisadi faaliyet kollarına dağılışına yönelik güncel verilerin bulunmamasıdır. TÜİK'in 2011 yılından itibaren milli gelir, işsizlik, işgücü ve istihdam gibi verileri illere göre değil, bölgelere göre açıklaması da kentsel nüfus çalışmalarının zorlukları arasında yer alır.

Kilis yerleşme açısından birçok medeniyete ev sahibi yapmış tarihi bir kenttir. Dolayısıyla yerleşmenin ana formu ve dokusu tarihi yapı üzerine kuruludur. Kentin sıkışık bir düzende yer almas1 nüfus yoğunluğunun da artışını beraberinde getirmiştir. Kentin nüfus artışında uzun zamandan beri etkili olan faktör ise ticaret olmuştur. Ticari fonksiyonun artış gösterdiği zamanlarda nüfus artışı da doğru orantılı olarak artış göstermiştir. Kentin il merkezi oluşu da kamusal yatırımlarla kentin büyümesine ve nüfus artışına etki eden faktörlerdendir. Günümüzde 100 bini aşmış nüfusuyla kent, orta büyüklükte bir şehir halindedir. Ayrıca 2011 yılında Suriye iç savaşından kaçan sığınmacıların etkisiyle nüfus taşıma kapasitesinin üzerinde nüfus barındıran bir kentsel alan haline gelmiştir. Ancak çalışmada verilen sayısal verilere Suriyeli sığınmacı nüfus dâhil edilmemiştir. Nüfus çok hızlı değişken bir yapıda olduğu için yapılan çalışmaların da belirli zamanlarda yenilenmesi gerekmektedir. Kilis kenti ile ilgili nüfus çalışmalarının da henüz bilimsel olarak ele alınmaması böyle bir çalışmanın yapılmasını teşvik etmiştir. 


\section{Bulgular \\ Nüfusun Gelişimi}

Şehirler küçük bir sahada, büyük nüfus kitlelerinin birlikte bulunduğu, geçimini temin ettiği yerleşmelerdir. Ancak şehirler çevrelerinden izole edilmiş yerleşmeler de değildir. Yakın çevre ve hinterlandları ile sıkı ekonomik ilişkileri bulunan insan topluluklarının yığılma sahalarıdır. Bu bakımdan denilebilir ki, bir şehrin büyüklüğü ve önemi; genellikle onun tesir sahasının, bilhassa iktisadi etki sahasının genişliği ve önemi ile orantılıdır. Şehirler aynı zamanda çevresindeki kırsal alanlardaki halkın ihtiyaçlarını karşılayan hizmetlere sahip bulunmaktadır. Hiçbir şehir kendi kendine yeterli değildir. Şehir, çevresindeki sahaların çeşitli hizmetlerin odağı durumundadır. Çeşitli hizmetleri ile şehir, çevresindeki sahayı dolaylı ve dolaysız olarak etkilemektedir. Bu hizmetler şehir dışında ne kadar uzaklara yayılır ise, şehrin önemi o derece büyüktür (Göney, 1977: 1-3). Buna göre Kilis kentinin etki sahasının dar olması, kırsal kesimde yer alan nüfusun da azalması kenti besleyen nüfus potansiyelini olumsuz etkilemektedir.

Kilis kenti nüfus gelişimini dönemlere ayırarak incelemek konuya daha sistematik yaklaşımı sağlayacaktır. Farklı medeniyetlerde var olmuş Kilis kenti uzun yerleşim tarihi sebebiyle nüfus gelişimi açısından karakteri birbirinden farklı birçok döneme ayrılabilir. Cumhuriyet öncesinde nüfus verilerinin sınırlı olması sebebiyle değerlendirmeler daha genel hatlarıyla yapılmıştır. Cumhuriyet sonrası dönemde ise verinin ulaşılabilir ve somut bilimsel metotlarla elde edilmesi nüfus gelişim dönemlerinin daha gerçekçi ortaya konulmasını sağlamıştır. Bu nedenle Kilis kenti nüfus gelişiminde Cumhuriyet öncesi dönem, Cumhuriyet sonrası 1920-1950 aras1 dönem nüfusun durağan seyrettiği dönem (durağan artış dönemi), 1950-1980 nüfusun hızlı şekilde artış gösterdiği dönem (dinamik artış dönemi), 1980 sonrası dönem ise nüfusun tekrar durağanlaştığı dönem (ikinci durağan artış dönemi) olarak ayrılabilir.

Kilis'in Osmanlı hâkimiyetine geçmesinden 3 yıl sonraki (1519) verilerine göre Kilis 1300 nüfusu ile kasaba görünümündedir. Elde edilen 1590 nüfus verisine göre yıllık nüfus artış hızı \%o 11,20 ile nüfus 2880 kişiye ulaşmıştır (Yıllık Hazırlama Komitesi, 1998). Nüfus artışıyla beraber Kilis'in çevresine göre merkezileştiği ve kırsalın pazar yeri haline geldiği ifade edilebilir. Dolayısıyla bu artış Kilis yerleşmesinin şehirsel özelliklerini tetikleyici rol üstlenmiştir. 17. Yüzyıl nüfusuna ilişkin bilgiler ise Evliya Çelebi'nin seyahatnamesinde yer almaktadır. Yüzyılın ikinci yarısına ait olan (1661) veriye göre Kilis şehri nüfusu 23.300 kişidir. Yaklaşık 70 yıllık zaman periyodunda Kilis nüfusu 8 kat artış göstermiştir (Tablo 1). Bu veri Kilis kentinin tam bir merkeziyet kazandığının göstergesidir. Artık Kilis çevresinden göç alan, kırsalın pazar yeri ve Halep çıkışlı veya varışlı kervanların uğrak yeri haline gelmiştir.

Tablo 1: Cumhuriyet Öncesi Dönem Kilis Kentinde Yıllara Göre Nüfus Gelişimi (1519-1902)

\begin{tabular}{ccccccccccc}
\hline Yıllar & $\mathbf{1 5 1 9}$ & $\mathbf{1 5 9 0}$ & $\mathbf{1 6 6 1}$ & $\mathbf{1 8 0 0}$ & $\mathbf{1 8 6 8}$ & $\mathbf{1 8 7 1}$ & $\mathbf{1 8 7 6}$ & $\mathbf{1 8 8 6}$ & $\mathbf{1 8 9 5}$ & $\mathbf{1 9 0 2}$ \\
\hline Nüfus & 1300 & 2880 & 23300 & 28674 & 24534 & 22805 & 23600 & 20500 & 21675 & 23500 \\
\hline Y.N.A.H \% & - & 11,2 & 29,44 & 1,48 & $-2,29$ & $-24,36$ & 6,85 & $-14,08$ & 6,19 & 11,55 \\
\hline
\end{tabular}

Kaynak: İncili, 2013

19. yüzyıla gelindiğinde Kilis nüfusuna ait veriler daha da çeşitlenmiştir. Osmanlı Devletinde ilk nüfus sayımı 1831 yılında yapılmış olsa da Halep Eyaletinde nüfus sayımı yapılmamıştır (Akbal, 1951: 57-60). Yine Aralık 1848 yılında eyaletin ve kazalarının nüfus sayımı yapılması için Halep Valisi Kamil Paşa'ya buyrultu gönderilmiş ise de, sayımın yapılıp yapılmadığı öğrenilememiştir (Güzelbey, 1992: 9). Yüzyılın ikinci yarısında ancak Halep Vilayet Salnamelerinde nüfus ile ilgili verilere ulaşılmıştır. Ancak bazı yıllardaki sayılar birbirinin aynısı olup tekrarlanan şekildedir. Bu nedenle nüfus verilerinin farklı kaydedildiği yıllar tercih edilerek kullanılmıștır. Halep Vilayet Salnamelerinde Kilis ile ilgili kazanın toplam nüfusu yer alıp bunun yanında şehirdeki konut sayıları verilmiştir. Konut sayılarından hareketle hane sayısı 5 rakamıyla çarpılarak muhtemel kentsel nüfusa ulaşılmıştır. Nitekim katsayıda "5" rakamı birçok araştırmacı 
tarafından benimsenmiştir (Gümüşçü, 2001: 146). 1661 yılından 1800 yılına kadar nüfusun artış hızının düştüğü (\%o 1.48) ifade edilebilir. Nitekim 19. Yüzyıl verilerine bakıldığında zaman zaman şehir nüfusunun azaldığı veya durağan hale geldiği görülmektedir (Tablo 1). Nüfusun durağan hale gelmesi kentin nüfus taşıma kapasitesine de yaklaşıldığını gösterir. Ancak bu yüzyılda var olan kıtlık, salgın hastalıklar, iç isyanlar ve savaşlar nüfus artış hızlarını etkileyen önemli olaylar olmuştur.

Tablo 2: Kilis Kentinde Nüfusun Gelişimi, Cinsiyet Oranları ve Nüfus Artış1 (1927-2019)

\begin{tabular}{|c|c|c|c|c|c|c|c|c|}
\hline \multirow{2}{*}{ Yillar } & \multirow{2}{*}{ Erkek } & \multirow{2}{*}{ Kadın } & \multirow{2}{*}{ Toplam } & \multirow{2}{*}{$\begin{array}{c}\text { Cinsiyet } \\
\text { Oranı }\end{array}$} & \multicolumn{2}{|c|}{ Nüfus Artış Oranı \% } & \multirow{2}{*}{ İl Nüfusu } & \multirow{2}{*}{$\begin{array}{c}\text { Kentin İl } \\
\text { Nüfusuna Oran }\end{array}$} \\
\hline & & & & & Dönemler & Kilis Kenti & & \\
\hline 1927 & 11477 & 11191 & 22668 & 103 & - & & 45765 & 49,53 \\
\hline 1935 & 12672 & 11960 & 24632 & 106 & $1927-1935$ & 8,66 & 56093 & 43,91 \\
\hline 1940 & 13485 & 13073 & 26558 & 103 & $1935-1940$ & 7,82 & 59775 & 44,43 \\
\hline 1945 & 13647 & 13401 & 27048 & 102 & $1940-1945$ & 1,85 & 62419 & 43,33 \\
\hline 1950 & 13885 & 13665 & 27550 & 102 & $1945-1950$ & 1,86 & 62329 & 44,20 \\
\hline 1955 & 15079 & 14885 & 29964 & 101 & $1950-1955$ & 8,77 & 63948 & 46,86 \\
\hline 1960 & 16669 & 16336 & 33005 & 102 & $1955-1960$ & 10,15 & 67382 & 48,98 \\
\hline 1965 & 19341 & 18754 & 38095 & 103 & $1960-1965$ & 15,42 & 75092 & 50,73 \\
\hline 1970 & 21777 & 21661 & 43438 & 101 & $1965-1970$ & 14,02 & 83913 & 51,77 \\
\hline 1975 & 28243 & 25812 & 54055 & 109 & $1970-1975$ & 24,44 & 92759 & 58,27 \\
\hline 1980 & 29024 & 29311 & 58335 & 99 & $1975-1980$ & 7,92 & 95419 & 61,14 \\
\hline 1985 & 29872 & 30004 & 59876 & 100 & $1980-1985$ & 2,64 & 101818 & 58,81 \\
\hline 1990 & 44380 & 38502 & 82882 & 115 & $1985-1990$ & 38,42 & 121752 & 68,07 \\
\hline 2000 & 35246 & 35424 & 70670 & 99 & $1990-2000$ & $-14,73$ & 114724 & 61,60 \\
\hline 2007 & 38322 & 39384 & 77706 & 97 & $2000-2007$ & 9,96 & 118457 & 65,60 \\
\hline 2008 & 38903 & 39795 & 78698 & 98 & $2007-2008$ & 1,28 & 120991 & 65,04 \\
\hline 2009 & 39991 & 40551 & 80542 & 99 & 2008-2009 & 2,34 & 122104 & 65,96 \\
\hline 2010 & 40523 & 41586 & 82109 & 97 & $2009-2010$ & 1,95 & 123135 & 66,68 \\
\hline 2011 & 41899 & 42285 & 84184 & 99 & $2010-2011$ & 2,53 & 124452 & 67,64 \\
\hline 2012 & 42557 & 42562 & 85119 & 100 & 2011-2012 & 1,11 & 124320 & 68,47 \\
\hline 2013 & 44351 & 45071 & 89422 & 98 & $2012-2013$ & 5,06 & 128586 & 69,54 \\
\hline 2014 & 44794 & 45533 & 90327 & 98 & 2013-2014 & 1,01 & 128781 & 70,14 \\
\hline 2015 & 46175 & 47091 & 93266 & 98 & 2014-2015 & 3,25 & 130655 & 71,38 \\
\hline 2016 & 46119 & 47103 & 93222 & 98 & $2015-2016$ & $-0,05$ & 130825 & 71,26 \\
\hline 2017 & 48525 & 49220 & 97745 & 99 & 2016-2017 & 4,85 & 136319 & 71,70 \\
\hline 2018 & 49955 & 50720 & 100675 & 98 & 2017-2018 & 3 & 142541 & 70,63 \\
\hline 2019 & 51660 & 52223 & 103883 & 99 & 2018-2019 & 3,19 & 142490 & 72,91 \\
\hline
\end{tabular}

Kaynak: DİE, Genel Nüfus Sayımları (1927-2000); TÜİK ADNKS Nüfus İstatistikleri (2007-2019)

1927-1950 arası dönem nüfusun durağan seyrettiği dönem (durağan artış dönemi) olarak ifade edilebilir (Tablo 2 ve Şekil 2). 1927 y1lı Genel Nüfus Sayımları sonuçlarına göre Kilis kent nüfusu 22.668 kişidir. Bu nüfusuyla Kilis, Türkiye'nin 22. büyük şehridir (Kesici, 1992). 1902 yılı elde edilen nüfus bilgilerine göre 1927 yılında bir gerilemenin olduğu görülmektedir (Tablo 1-2). Bu durum üzerinde, I. Dünya ve Kurtuluş savaşı (1914-1922) esnasında doğumların az, ölümlerin fazla gerçekleşmesi sonucu, 1940-1945 döneminde ana-baba olma çağındaki nüfus eksikliğinin yanı sıra, bu yıllarda II. Dünya Savaşının oluşturduğu olumsuzlukların etkili olduğu şüphesizdir (Özgür, 1998: 12). Ancak konuya ekonomik olarak bakmakta gerekmektedir. Çünkü Kilis uzun yıllar Halep ile bağlantısı sayesinde nüfusunu korumuş önemli bir merkezdir. Ancak 1921 yılında Türkiye-Suriye sınırının çizilmesiyle Kilis, Halep ile olan sıkı ilişkisel ağını kaybetmiştir. Ayrıca kenti besleyen kırsalı da Suriye toprakları içerisinde kalmıştır. Bu durum nüfus kaybına sebep 
olmuştur. Dolayısıyla bir yandan yönetim bölgesindeki daralma, yanı başındaki Gaziantep'in önemli bir merkeziyet kazanarak Kilis'in ekonomik etki bölgesini daraltması bu dönemde kentin nüfus potansiyelini etkilemiştir. Nitekim Türkiye'de birçok kentin nüfusu hızlı artış gösterirken Kilis kenti nüfusu nisbi olarak gerilemiştir. Bu gerileme sebebiyle 1950 sayımlarında Kilis 42. büyük şehir durumuna düşmüştür (Kesici, 1992).

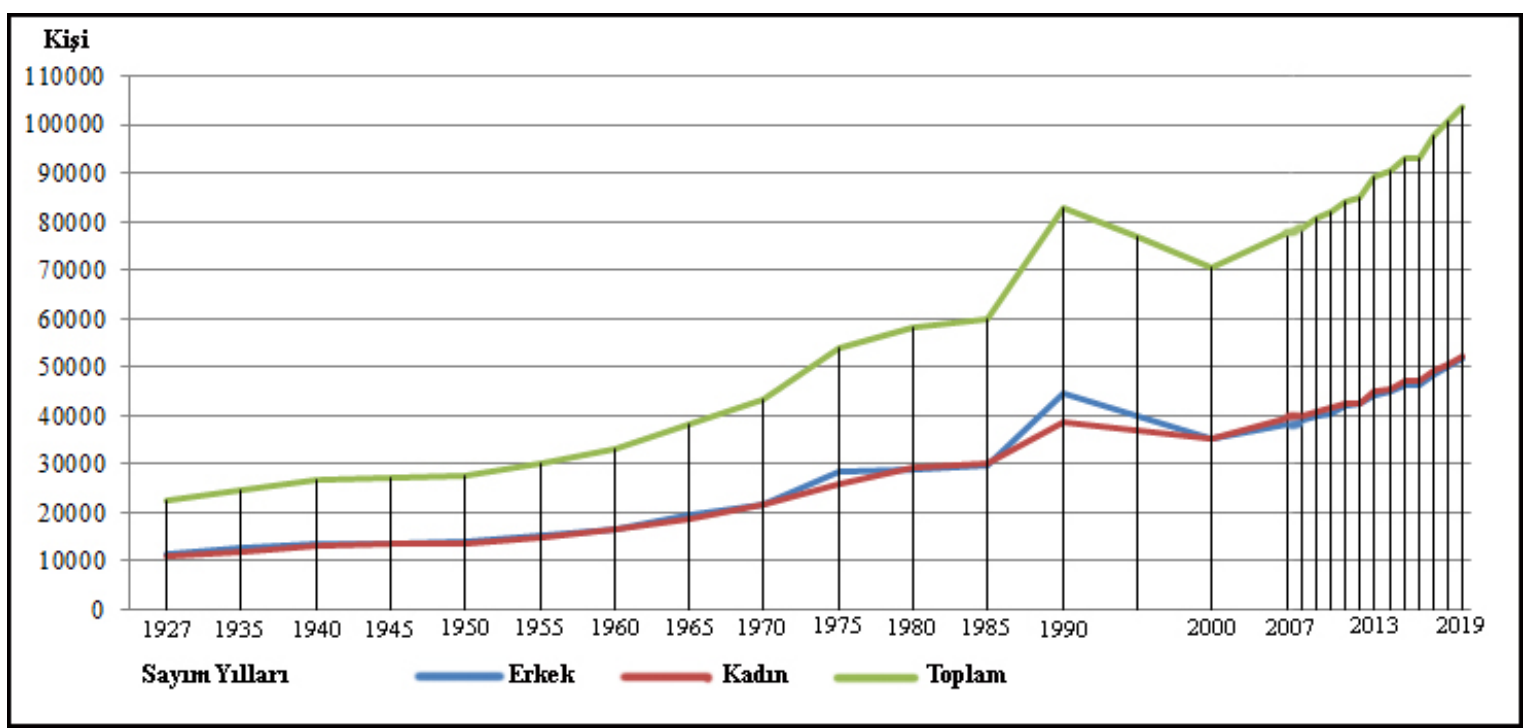

Şekil 2. Kilis Kenti Nüfus Gelişimi (1927-2019)

1950-1980 nüfusun hızlı şekilde artış gösterdiği dönem (dinamik artış dönemi) olarak görülmektedir (Tablo 2 ve Şekil 2). Türkiye genelinde olduğu gibi, Kilis’te de yıllık nüfus artış hızının yükseldiği görülmektedir. Bu dönemdeki artışın temel nedeni II. Dünya Savaşı'nın sona ermesi ve dolayısıyla da seferberlik koşullarının ortadan kalkması sonucu, silahaltına alınan erkeklerin evlerine dönmesiyle evlenmelerin ve doğumların artmış olması iken; diğer taraftan da ekonomik, sosyal ve sağlık alanında başlayan olumlu gelișmelerdir (Doğanay, 1997; Tandoğan, 1998; Özgür, 1998).

Kilis'te bu dönemdeki nüfus artışının sebebi kentin ticari aktivitesinin yeniden yükselmesi birinci derecede etkili olmuştur. 1950'li yıllarla birlikte, özellikle de 1960'dan sonra, sınırın mayınlanmasıyla (1958) artan gayri resmi sınır ticaretine bağlı olarak oluşan yüksek ticari kapasite şehre canlılık getirmiştir (Kesici, 1992: 250-251). Bu olayda Kilis'in potansiyelinin ticari aktiviteye bağlı olduğunu bir kez daha göstermiştir. Özellikle nüfus artış oranında 1970-1975 döneminde \% 24.44'lük değere ulaşılması artan ticari aktiviteyle ilişkilidir. Kentteki yüksek ticari aktivite kırsaldaki nüfusu kente çeker bir özellikte göstermiştir. Tabloda (2) da görüldüğü gibi bir önceki dönemde \%51 olan kentin il nüfusuna oran1 1970-1975 döneminde \%58'e yükselmiştir. Bu durum kırsaldan kente göçün bir göstergesi olmuştur. 1978 yılında sıkıyönetim ilanı ve 12 Eylül 1980 Askeri Darbesinin gayri resmi sınır ticaretine son vermesiyle nüfusun dinamik artış dönemi son bulmuştur.

1980 sonras1 dönem nüfusun tekrar durağanlaştığ dönem (ikinci durağan artış dönemi) olarak görülür. 1980-1985 döneminde nüfus artış oranının \% 2.64'e düştüğü görülmektedir. Bu sert düşüş Kilis'in ticari aktivitesini kaybetmesiyle alakalıdır. Ancak bu dönem içinde 1985-1990'da \% $38,42^{\prime}$ lik bir artış oranı görülmektedir (Tablo 2). Bu artış oranı suni yaşanmış bir artış oranı olarak izah edilebilir. Çünkü 1990 sayım yılında Kilis'in il olma ihtimali dillendirildiğinden nüfus sayımında çok sayıda kişi diğer illerden şehre geçici olarak taşınarak nüfusun olduğundan fazla gösterilmesi sağlanmıştır. 1995 yılında il statüsüne kavuşan Kilis’te kamusal hizmetlerin artış göstermesi sebebiyle 2000 sayımında, 1990 sayımına göre artış görülmesi beklenirdi. Ancak 1990 nüfus sayımında suni artış sağlandığından dolayı, il statüsüne kavuşmuş olmasına rağmen, 2000 
sayım yılında ciddi bir azalış görülmüştür. Nitekim 1990-2000 döneminde nüfus bir önceki döneme göre \% -14.73 oranında azalmıştır (Tablo 2). Suni artışın diğer tespiti ise sayım yıllarındaki cinsiyet oranından izlenebilir. 1990 yılında cinsiyet oranının 115 olarak görülmesi sayım günü diğer illerden getirilen erkek nüfus ile açıklanabilir. Kentin il nüfusuna oranına bakıldığında yine dışardan getirilen nüfus kentsel nüfus içerisinde gösterilmesi sebebiyle suni yükseklik görülmüştür. Dolayısıyla durağan dönem içerisinde 1990 yılındaki suni nüfus artışı kentin gerçek durumunu yansıtmadığı için göz ardı edilmiştir. 2007 yılında il olmanın getirmiş olduğu yatırımlar ve Kilis 7 Aralık Üniversitesi'nin kurulması nüfus artışını tekrar hızlandırmıştır. Bu dönemde Türkiye-Suriye ilişkilerindeki iyileşme ve ticari aktivite (2005-2010) Kilis'te tekrar ticaretin canlanmasına sebep olmuş ve nüfus artışına yansımıştır. Ancak 2011 Suriye iç savaşının başlamasıyla birlikte Kilis'te yeniden ticari aktivite azalma göstermiştir. 2011 yllından sonra Kilis nüfus seyrinde Suriye iç savaşının etkileri kuvvetli hissedilmiştir. Kilis'in Suriyeli sığınmacı göçüne yoğun bir şekilde maruz kalması artan sığınmacı nüfus için daha fazla kamu çalışanına (öğretmen, polis, özel güvenlik vb.) ihtiyaç duyulması anlamına gelir. Dolayısıyla 2011 yılından sonra sığınmacı nüfusa odaklı artışlar yaşanmıştır. 2016 yılı bu dönem içerisinde önemli bir yer tutar. Bu yıl, Kilis'e Suriye tarafından roket atılması sonucu göç yaşanmasına sebep olmuş ve nüfus artış hızı negatif değerlere düşmüştür. Ancak sonrasında Fırat Kalkanı ve Zeytin Dalı Askeri harekâtlarıyla var olan sıkıntılı durum sona ermiş ve nüfus artış hızı tekrar artış göstermiştir. Ancak bu artışta bahsedildiği üzere kentteki kamu görevlileri etkili olmuştur.

Kilis kenti cinsiyet oranlarında 1980 y1lına kadar erkek nüfus fazla iken 1980 sonrasında genel olarak kadın nüfus fazlalığı söz konusudur (Tablo 2). İş olanaklarının az olduğu kentlerde genellikle kadın nüfus fazlalığının görülmesi Kilis’te de iş olanaklarının azlığını açıklar. Kentin il oranına nüfusuna bakıldığında ise yükselme eğilimi görülebilmektedir. 1927 yılı Türkiye'de kentsel nüfus oran1 \%25 iken Kilis'te bu oran \%49,53'tür. 2012 yılı Türkiye'de kentsel nüfus oranı $\% 77$ iken Kilis’te \%68,47 olmuştur (Tablo 2). Buna göre Kilis’te kentleşme hızı Türkiye ortalamasından daha düşük seyretmiştir.

Gelecekte Kilis kent nüfusu durağanlığını sürdürecek gibi görülmektedir. Kent nüfusu üç modelin ortalamasına göre 2050 yılında yaklaşık 185 bin olarak ön görülmektedir. Üç modelden en yüksek olanı 2050 yılında 233.506 nüfusu ön gören geometrik artış modelidir. En düşük ise iller bankası modeline göre olup nüfus 141.419 olarak ön görülmüştür (Şekil 3). Kilis'in gelecekteki kent nüfusunu tahmin etmek gerçekten çok zordur. İşin içerisinde Suriye denkleminin olması ve bu durumun da şu an için belirsizliği Kilis'in gelecekteki durumunu ve nüfusunu etkileyecektir. Şunu da söylemek gerekir ki bugün Kilis kent nüfusu Suriyeli sığınmacı nüfus ile birlikte düşünüldüğünde 200 bin civarındadır. Bu rakam kentin nüfus taşıma kapasitesi ve alt yapısı hakkında önemli bir veriyi de meydana getirmektedir. 


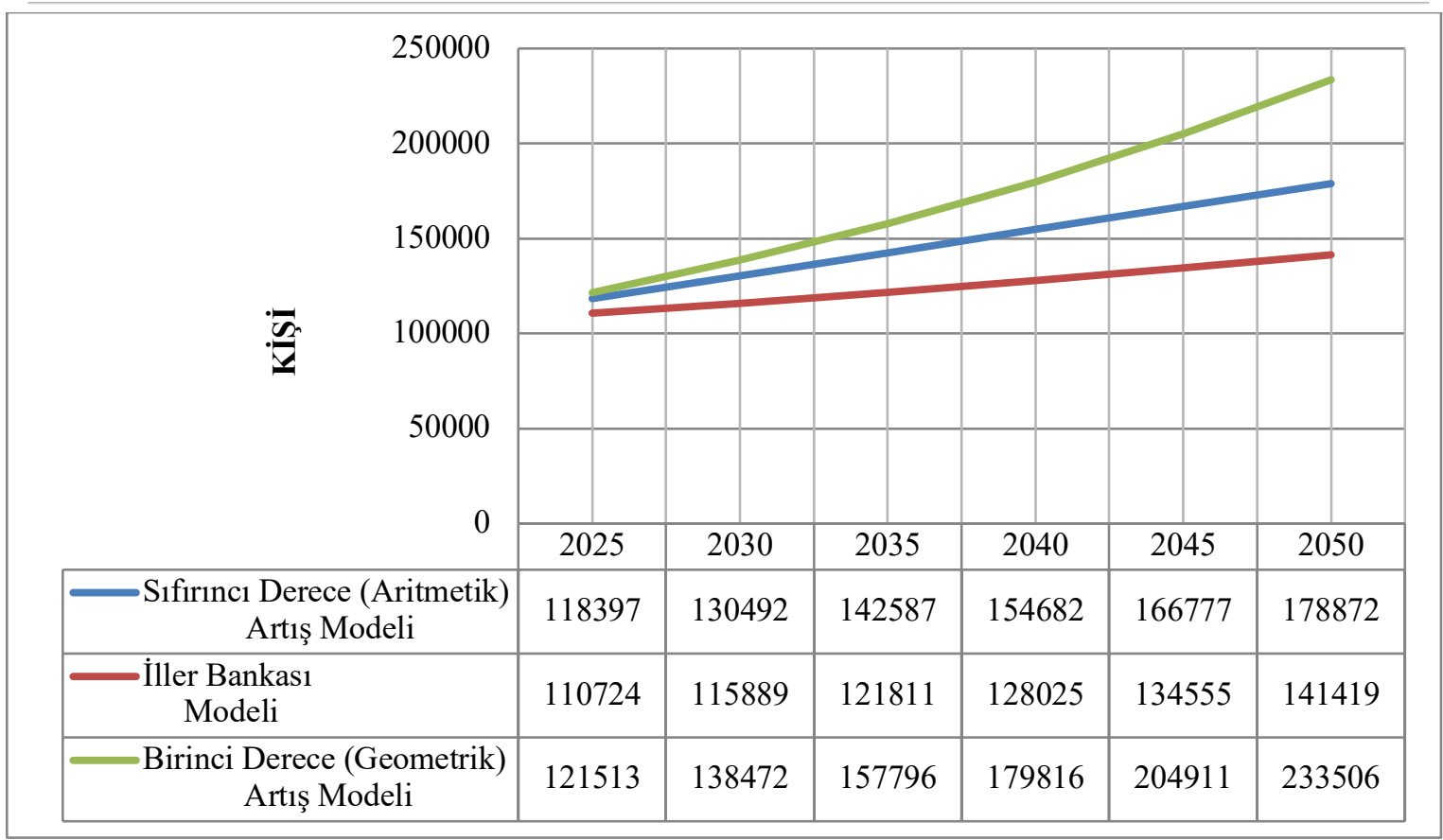

Şekil 3. Kilis Kent Nüfusu Projeksiyonları (2025-2050)

\section{Nüfus Hareketleri}

Nüfus hareketleri doğum, ölüm ve göç olaylarını kapsayan temel demografik konulardandır. Eğer göç olayları hesaba katılmazsa bir yerdeki doğumlar ile ölümler arasındaki fark doğal nüfus artış oranını verir. Doğumlar ile ölümler arasındaki fark nüfus artışında etkili olan temel belirleyicilerdir. Ayrıca doğum çağında kabul edilen kadın nüfus sayısı, toplam doğum sayıları ve doğurganlık hızı nüfusun hareket ve artışında önemli ipuçları verir. Nüfusun göçlerle birlikte hareket kazanması ise bazı yerleşmelerde nüfusun yoğunlaşmasına, bazı alanlarda ise nüfusun seyrekleşmesine sebep olur. İşte doğumlar ve ölümler dışında göçlerle de nüfusun değişimine genel nüfus değişimi adı verilmektedir. Günümüzde ulaşım faktörünün hızlı ve güvenli oluşu özellikle kentlerde genel nüfus değişimini ön plana çıkarmaktadır.

Tablo (3) incelendiğinde nüfus artışına paralel olarak 15-49 yaş kadın nüfusu da artış göstermektedir. Ancak bu artışa rağmen toplam doğum sayılarında düşüşler görülmektedir. 2000 yılında 15-49 yaş kadın nüfus 12.430 olup toplam doğum sayısı 2813 iken 2018'de 26.765 kadın nüfus olup toplam 2347 doğum görülmüştür. $\mathrm{Bu}$ düşüş doğurganlık hızlarında da kendini göstermektedir. 2000 yılı doğurganlık hızı \%o226; 2014'de \%o102; 2018'de ise \%o88'e gerilemiştir. Doğurganlık hızındaki düşüş kentleşme, kadın nüfustaki çalışma oranının artışı ve çekirdek aile tipine doğru yönelimden kaynaklanmaktadır. Son yıllarda Kilis'in kamu sektörüne yönelik göç alması kentte geleneksel geniş aile tipinden ziyade çekirdek aile tipinin artış göstermesinde etkili olmuştur. Bu yapı da doğurganlık hızındaki hızlı düşüşü meydana getirmiştir.

Tablo 3: Kilis Kentinde Doğumlar, Ölümler ve Doğal Nüfus Artış Oranı (2000, 2014, 2018)

\begin{tabular}{ccccccccc}
\hline Yıllar & $\begin{array}{c}\mathbf{1 5 - 4 9} \\
\text { Kadın } \\
\text { Nüfus } \\
\text { Sayısı }\end{array}$ & $\begin{array}{c}\text { Toplam } \\
\text { Nüfus }\end{array}$ & $\begin{array}{c}\text { Doğum } \\
\text { Sayısı }\end{array}$ & $\begin{array}{c}\text { Ölüm } \\
\text { Sayısı }\end{array}$ & $\begin{array}{c}\text { Doğurganlık } \\
\text { Hızı \%o }\end{array}$ & $\begin{array}{c}\text { Kaba } \\
\text { Doğum } \\
\text { Hızı \%o }\end{array}$ & $\begin{array}{c}\text { Kaba } \\
\text { Ölüm } \\
\text { Hızı \%o }\end{array}$ & $\begin{array}{c}\text { Doğal Nüfus } \\
\text { Artış Oranı } \\
\text { \%o }\end{array}$ \\
\hline 2000 & 12430 & 70670 & 2813 & 550 & 226 & 39,8 & 7,8 & 32,0 \\
\hline 2014 & 24189 & 90327 & 2456 & 603 & 102 & 27,2 & 6,7 & 20,5 \\
\hline 2018 & 26765 & 100675 & 2347 & 607 & 88 & 23,3 & 6,0 & 17,3 \\
\hline
\end{tabular}

Kaynak: TÜİK, Doğum, Ölüm ve Nüfus İstatistikleri (2000, 2014, 2018); 2000 Genel Nüfus Sayımı (Kilis) 
Doğum ve ölümler arasındaki farktan hareketle Kilis kenti doğal nüfus artış oranı 2000 y1lında \%o32; 2014 yllında \%20,5; 2018 yilında ise \%o17,3 olmuştur (Tablo 3). Doğum sayılarındaki düşüş doğal nüfus artış oranındaki düşüşü de meydana getirmiştir. 2013-2014 dönemi nüfus artı̧̧ oranı \%010,01 olarak gerçekleşmişti. Ancak 2014 doğal nüfus artış oranı ise \%o20,5'dir. $\mathrm{Bu}$ durumda Kilis'in dışa göç verdiği anlaşı1ır. 2017-2018 dönemi nüfus artış oranı \%o30 olarak görülmüştü. Ancak 2018 y1lı doğal nüfus artış oranı ise \%17,3'tür. Bu durumda Kilis'in diğer illerden göç aldığı sonucuna ulaşılabilir.

Birçok bilimin araştırma konuları içerisinde yer alan göç olgusu, özellikle nüfusun dağglışı üzerinde belirleyici olması ile neden ve sonuçları itibariyle coğrafyanın da öncelikli inceleme alanlarından biridir. Nitekim göçler, yerleşmelerin nüfuslarını etkilediği gibi nüfusun demografik yapısında da önemli değişikliklere neden olabilmektedir. Nüfusun; devamlı yaşam bölgelerini kişisel, aileler ve gruplar halinde terk edip, geçici ya da sürekli olarak yaşamak amacıyla bir başka yere gitmesi (Doğanay, 1997) şeklinde tanımlanabilecek olan göç; bir taraftan nedenleri, diğer taraftan da hem göç alan, hem de göç veren bölgelerdeki sonuçları itibariyle önemle üzerinde durulması gereken bir olgudur (Doğanay ve Orhan, 2014: 12).

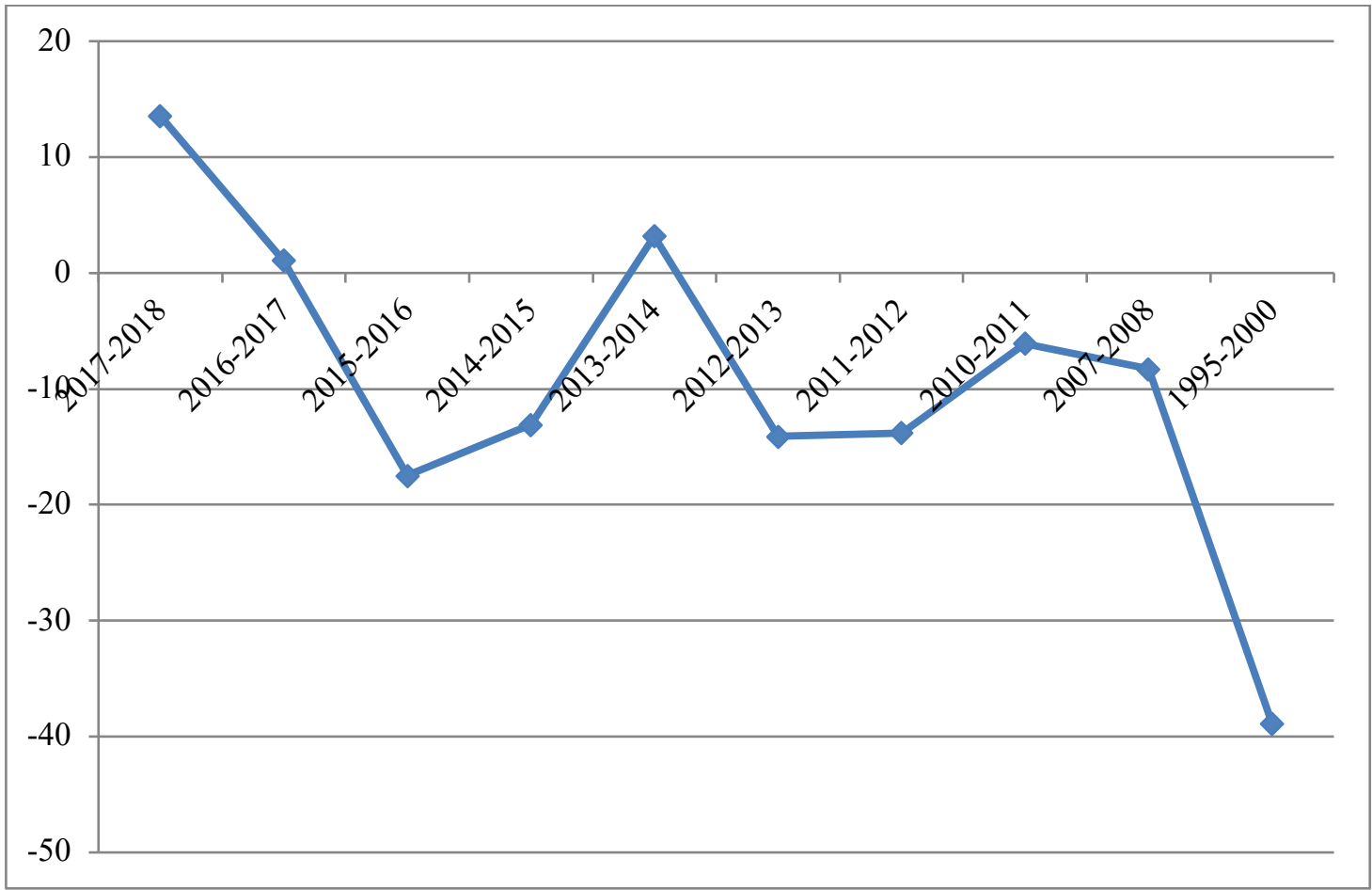

Şekil 4. Kilis İli Dönemlere Göre Net Göç Hızı

Göç nüfus hareketlerinde dinamizmi sağlayan bir bileşendir. Günümüzde göç; hızlı, rahat ve güvenli yapıldığı için nüfus hareketliliği de artmıştır. Dolayısıyla göç, toplumu ve mekânı değiştiren bir faktör olarak coğrafya çalışmalarında oldukça önem arz etmektedir. Kilis'te göç, uzun tarihi boyunca ticari aktivitelere bağlı olarak artış veya azalıșlar göstermiștir. Ticaret fonksiyonunun zaman zaman zayıflaması nüfusa istihdam yaratmadaki yetersizlikleri beraberinde getirerek Kilis kenti göç vermiştir. Grafikte (Şekil 4) son 20 yıllık periyottaki Kilis ili göç hızları incelendiğinde çoğunlukla göç hızlarının negatifte seyrettiği görülmektedir. Bu oranlar Kilis'in nüfus tutma kapasitesinin düşüklüğünü gösterir. Ancak 2016 y1lından itibaren kentte artan kamu görevlileri göç oranlarının yükselmesini sağlamıştır. Ancak şu ifade edilebilir ki hala yeteri kadar istihdam yaratmada yetersiz kalan Kilis halkı özellikle iş imkânlarının yüksek olduğu kentlere doğru göç etmektedir. 


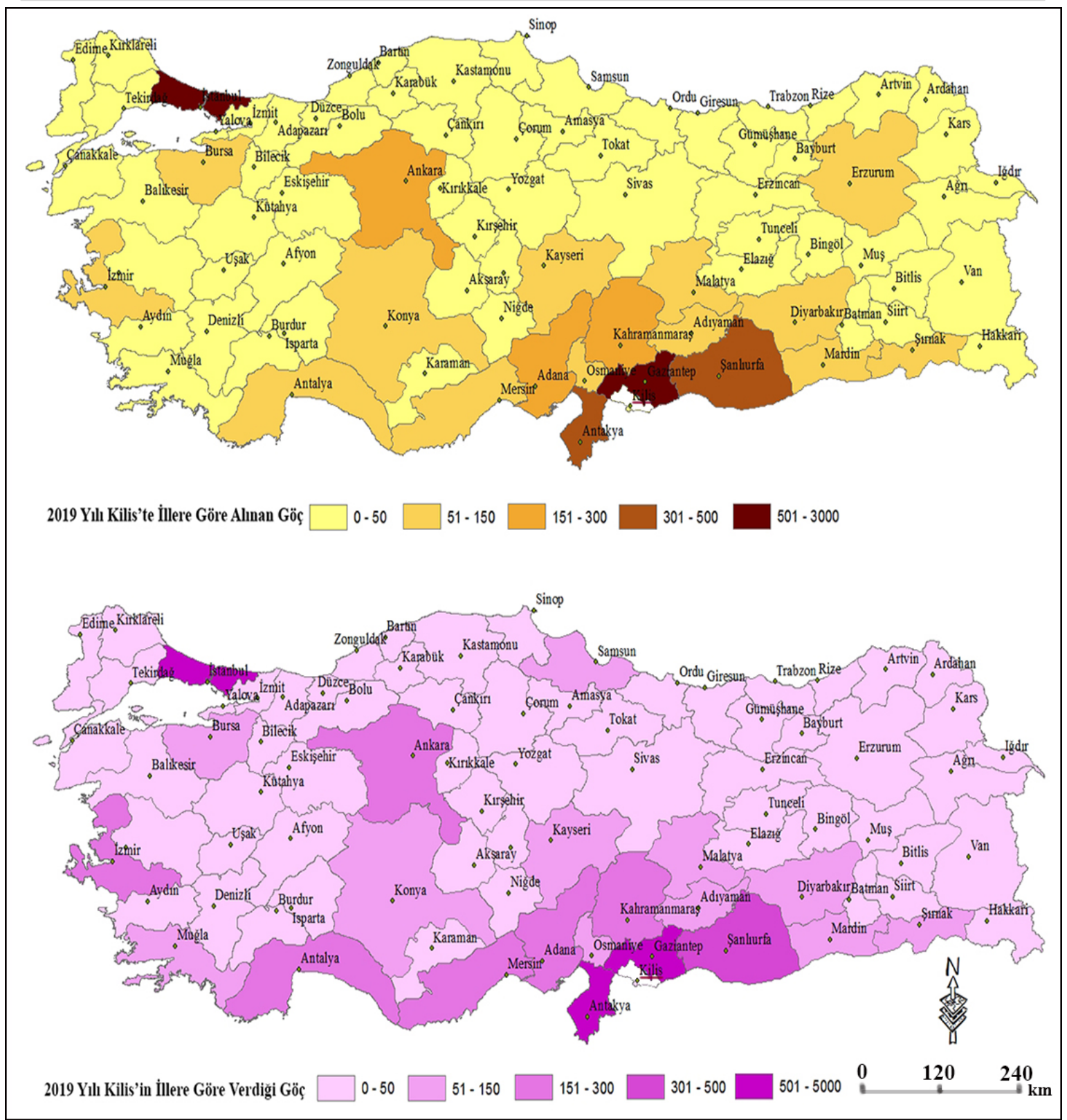

Şekil 5. 2019 Yılı Kilis İlinin Diğer İllerden Aldığı Göç ve Verdiği Göç Nüfus Haritası (TÜIK, Nüfus Verilerinden yararlanılarak hazırlanmıştır)

Haritada (Şekil 5) görüleceği üzere Kilis ili en fazla göçü yakın çevre illerden almaktadır. Özellikle Gaziantep, Hatay ve Şanlıurfa bu iller arasındadır. Bu illerden gelen göç üzerinde üniversite öğrencilerinin etkisi önemlidir. İstanbul'dan alınan göçün yüksek olması ise önceden göç etmiş ailelerin tekrar Kilis'e geri göçü ile açıklanabilir. 2019 y1lı verilerine göre toplam 6515 kişi Kilis iline göç etmiştir. Kilis'in 2019 yılı verdiği göçlere bakıldığında ise en fazla göçün yakın iller olan Gaziantep, Antakya ve Şanlıurfa; turizm merkezleri olan Antalya, Mersin, İzmir ve Muğla; iş imkânlarının fazla olduğu ve ağ sistemleriyle göçün hızlandığı İstanbul yer almaktadır. 2019 yılındaki toplam Kilis’ten diğer illere göç eden nüfus 8843 kişi olmuştur. Bu göçler yukarıda da ifade edildiği üzere çoğunlukla ekonomik sebepli göçlerdir. 


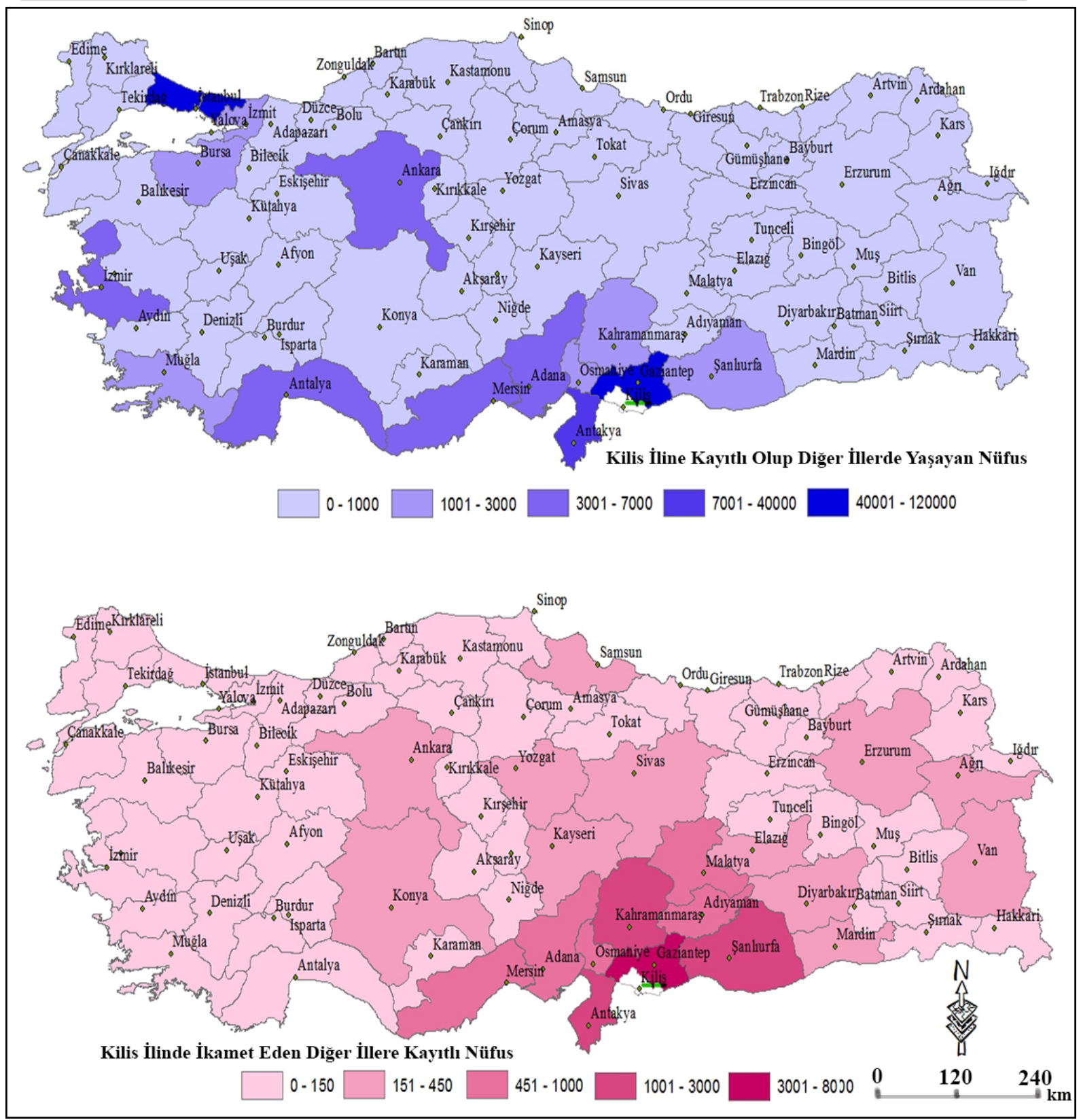

Şekil 6. 2019 Yılı Kilis İlinin Doğum Yerine ve İkamet Yerine Göre İller Bazında Dağılış1 (TÜIK, Nüfus Verilerinden yararlanılarak hazırlanmıştır)

Kilis ili nüfusuna kayıtlı olup diğer illerde yaşayan kişi sayısına bakıldığında Kilis'in çok fazla göç verdiği görülür. Toplam 210.333 kişi Kilis nüfusuna kayıtlı olup diğer illerde yaşamlarını sürdürmektedirler. Eğer Kilis göç vermeseydi bugün nüfusu 350 bin olacaktı. En fazla göç verilen il coğrafi yakınlık sebebiyle Gaziantep olmuştur. Toplam 110.389 Kilis nüfusuna kayıtlı kişi Gaziantep ilinde yaşamını sürdürmektedir. Yani Kilis kentinde yaşayan kişi sayısı kadar nüfus Gaziantep'e göç ederek orada yaşamını sürdürmektedir. Gaziantep'e olan göç üzerinde coğrafi yakınlık, ulaşımın kolay sağlanması, iş olanakları ve kültürel bağların fazlalığı etkili olmuştur. Göçün yoğunlaştığı diğer bir il 40.971 kişi ile İstanbul'dur. İstanbul'a yoğun göç sebepleri arasında ise iş olanakları ve hâlâ etkisini sürdüren hemşericilik göç üzerinde etkili olmaktadır. Kilis’ten göç eden nüfusun büyük kısmının İstanbul'da Yenibosna ve Şirinevler semtlerine yönelmesi buradaki ağ sisteminin oluşmasını sağlamıştır. Bu faktör göçü teşvik edici bir sistem oluşturmuştur. Göçün 
yöneldiği diğer iller ise yine coğrafi yakınlık sebebiyle Hatay (7171 kişi) ve Adana (5599 kişi) illeridir. Ayrıca turizm merkezleri olan Mersin, Antalya ve İzmir ile daha çok öğrenci göçünün yoğun yaşandığg Ankara Kilis'in yoğun göç verdiği alanlardır (Şekil 6).

Kilis'te yaşayan nüfus içerisinde başka illere kayıtlı olan nüfus değerlendirildiğinde toplam sayının 23.896 kişi olduğu görülmektedir. Bu rakam Kilis’in verdiği göçle kıyaslanamayacak derecede düşük kalmaktadır. Harita (Șekil 6) incelendiğinde yine coğrafi yakınlığın etkisi hissedilmektedir. Gaziantep nüfusuna kayıtlı olup Kilis'te yaşayan kişi sayısı 7085'dir. Diğer yoğunluk gösteren iller ise Hatay (2707 kişi), Şanlıurfa (1861 kişi) ve Kahramanmaraş (1737 kişi)'tır.

\section{Nüfusun Dağılışı}

Nüfus ve mekân ilişkilerini ortaya koyabilmek için bir yerde bulunan nüfusu mekân parçalarına en doğru şekilde dağıtmak gerekir. 1590 yılı verilerine göre Kilis şehri 5 mahalleden ibaretti. Bugün isimleri tamamıyla farklı olan bu 5 mahalle şehrin nüvesi görevini üstlenmiştir. Bu tarihte mahallelere göre dağıtılmış nüfus yoğunluğuna bakıldığında en fazla yoğunluğun, şehrin en önemli anıtsal yapıtı Tekye (Canbolad Paşa) Caminin içinde bulunduğu ve cami-hamam-pazar üçlemesinin de bulunduğu ticari fonksiyonun merkezi konumundaki Tekye Mahallesinde (16. yüzyılda Kana Mahallesi) olduğu görülür. Diğer mahalleler ise nüfus olarak daha az yoğunlukta olan Nurettin (16. Yüzy1lda Sübbat/Sibat Mahallesi), Mihali (XVI. yüzy1lda Kıbeliye), Karaali (XVI. yüzyılda Kızılca) ve Meşhetlik (XVI. yüzyılda Meşşata) Mahalleleridir (İncili, 2013).

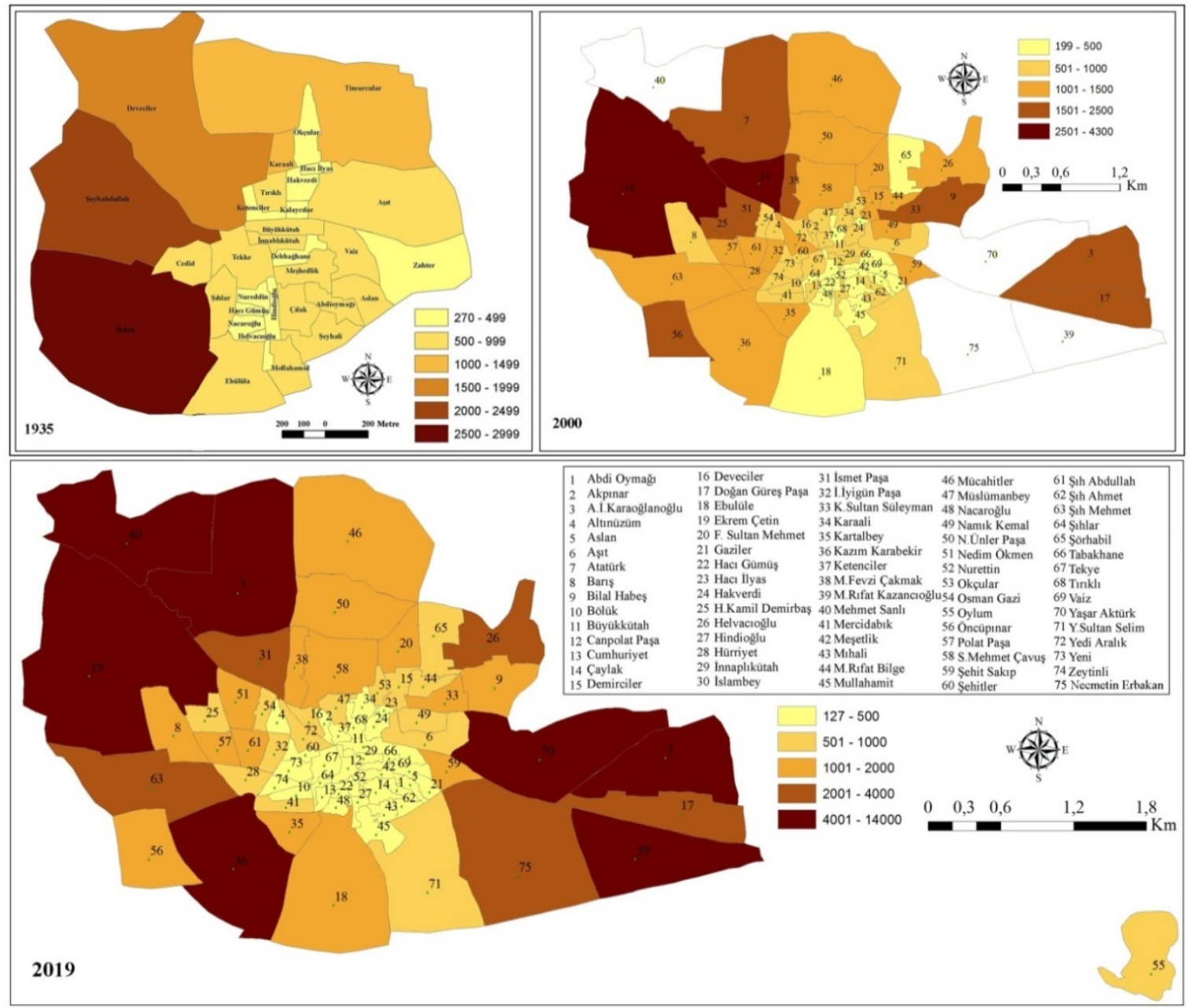

Şekil 7. Kilis Kentinde Nüfusun Mahallelere Göre Dağılımı (1935-2000-2019) 
1935 yılı muhtemel nüfus dağılışında şehrin merkezi ve güney doğu kesimlerindeki mahallelerin küçük yüzölçümlü, bu mahalleleri çevreleyen dış mahallelerin ise büyük yüzölçümlü olduğu dikkati çeker. 32 mahallenin yer aldığı kentte Bölük, Şıh Abdullah, Deveciler, Timurcular (Demirciler) ve Aşıt dış mahalleler olup nüfusun yüksek olduğu görülür. Dış mahallelerin hem alan hem de nüfus açısından büyüklüğü kentsel gelişimin sürdüğünün göstergesidir. Bu mahallelere genellikle kırsaldan göç eden nüfusun yerleşmesi söz konusu olmuştur. Şehrin merkezi mahallelerinde ise yüzölçümü yanı sıra nüfusun da az olduğu görülmektedir. Bu azlık yüzölçümü küçüklüğüne bağlanabileceği gibi merkezi mahallelerde iş ve ticaret alanlarının yer alması konut sayısının düşük olmasına dolayısıyla nüfusun da az olmasına sebep olmuştur. Nitekim Haciilyas, Hacıgümüş, Nacaroğlu, Hakverdi, Helvacıoğlu, Hindioğlu, Kalaycılar, Ketenciler ve Nureddin mahallelerinde yüzölçümü küçüklüğü sebebiyle nüfus da azdır. İş ve ticaret alanlarının yoğunlaştığı Tekye, Büyükkütah, İnnablıkütah mahalleleri merkezi iş ve ticaret alanlarının yoğunlaşma alanlarını meydana getirmiştir. Merkezi iş ve ticaret alanları yakınındaki Çılak, Vaiz, Abdioymağı, Aslan mahallelerinde ise nüfusun arttığı dikkati çeker (Şekil 7). Nüfus sayılarının aksine nüfus yoğunlukları açısından değerlendirildiğinde ise merkez mahallelerin yüzölçümü küçüklüğü sebebiyle yoğunluğun yüksek olduğu görülür. Dış mahallelerde ise yüzölçümünün büyüklüğü nüfus yoğunluğunun düşmesine sebep olmuştur.

Kilis kentinde yerleşmeyi etkileyecek topografya etkisinin zayıflığı, mahalleleri birbirinden ayıracak fiziki faktörlerin olmaması, eski kent merkezinin çıkmaz sokaklarla karakterize oluşu ve kent tarihinin köklü olması çok mahalleli bir yapıyı ortaya çıkarmıştır. 2000 yılı mahallelere göre nüfus dağılışında 70 mahallenin var olduğu görülmektedir. 1935 yılında dairevi olan kent formu 2000 yılında bozulmaya başlamıştır. 1935 yılında kentin diş mahalleleri olarak görülen Bölük, Şıh Abdullah, Deveciler, Demirciler 2000 yılı nüfus dağılış haritasında kentin merkezinde kalmış ve yüzölçümleri küçülmüştür. Kentin yeni dış mahalleleri Ekrem Çetin, Atatürk, Mücahitler, Kazım Karabekir, Şı Mehmet, Ebulüle ve Yavuz Sultan Selim olmuştur. Ayrıca 1991 yılında yerleşmeye açılan Öncüpınar Mahallesi, sınırda yer alan Öncüpınar (Tibil) köyünün taşınması sonucu kentin dış mahallesini meydana getirmiştir. Kentin doğusunda ise Beşevler semti adı verilen Albay İbrahim Karaoğlanoğlu ve Doğan Güreş Paşa Mahallelerinin gelişim gösterdiği görülür. 2000 yılı mahallelere göre nüfus dağılış haritasında yine dış mahallelerin yüzölçümü bakımından büyük ve nüfusça fazla oldukları görülmektedir (Şekil 7 - Tablo 4). Kentin iç mahallelerinde ise yüzölçümünün küçük ve nüfusun az olduğu görülür. Ancak bu merkez mahallelerde alanın küçüklüğüne bağlı olarak yoğunluğun yüksek olduğu ifade edilebilir.

Tablo 4: Kilis Kentinde Nüfusun Mahallelere Göre Dağılışı (2000-2010-2019) ve Mahallelere Göre Konut ve Özel İșyeri Sayıları (1990-2015-2019)

\begin{tabular}{|c|c|c|c|c|c|c|c|c|c|c|c|c|c|c|c|}
\hline \multirow{2}{*}{ Mahalleler } & \multicolumn{3}{|c|}{ Toplam Nüfus } & \multicolumn{2}{|c|}{$\begin{array}{c}\text { Nüfus Artış } \\
\text { Oranı \% }\end{array}$} & \multicolumn{3}{|c|}{ Konut Sayısı } & \multicolumn{3}{|c|}{ Fark } & \multicolumn{2}{|c|}{ İş Yeri Sayısı } & \multicolumn{2}{|c|}{ Fark } \\
\hline & 2000 & 2010 & 2019 & $\begin{array}{l}2000 \\
2019\end{array}$ & $\begin{array}{l}2010 \\
2019\end{array}$ & 1990 & 2015 & 2019 & $\begin{array}{l}2019 \\
1990\end{array}$ & $\begin{array}{l}2019 \\
2015\end{array}$ & 1990 & 2015 & 2019 & $\begin{array}{l}2019 \\
1990\end{array}$ & $\begin{array}{l}2019 \\
2015\end{array}$ \\
\hline Abdioymağı & 514 & 399 & 272 & $-47,1$ & $-31,8$ & 125 & 158 & 201 & 76 & 43 & 15 & 21 & 19 & 4 & -2 \\
\hline Akpınar & 565 & 480 & 332 & $-41,2$ & $-30,8$ & & 160 & 194 & 194 & 34 & & 49 & 45 & 45 & -4 \\
\hline Albay İbrahim Karaoğlanoğlu & 2358 & 2948 & 5572 & 136,3 & 89,0 & 340 & 1624 & 2119 & 1779 & 495 & 32 & 214 & 190 & 158 & -24 \\
\hline Altınüzüm & 642 & 643 & 474 & $-26,2$ & $-26,3$ & & 269 & 328 & 328 & 59 & & 112 & 111 & 111 & -1 \\
\hline Aslan & 407 & 323 & 197 & $-51,6$ & $-39,0$ & 215 & 122 & 150 & -65 & 28 & 30 & 30 & 13 & -17 & -17 \\
\hline Aşıt & 978 & 1106 & 974 & $-0,4$ & $-11,9$ & 658 & 460 & 508 & -150 & 48 & 72 & 130 & 118 & 46 & -12 \\
\hline Atatürk & 1687 & 2129 & 5015 & 197,3 & 135,6 & & 2251 & 2878 & 2878 & 627 & & 113 & 119 & 119 & 6 \\
\hline Barış & 700 & 789 & 1295 & 85,0 & 64,1 & & 451 & 556 & 556 & 105 & & 59 & 62 & 62 & 3 \\
\hline Bilali Habeş & 1728 & 1824 & 1858 & 7,5 & 1,9 & & 543 & 738 & 738 & 195 & & 64 & 75 & 75 & 11 \\
\hline Bölük & 587 & 634 & 422 & $-28,1$ & $-33,4$ & 1366 & 217 & 271 & -1095 & 54 & 135 & 11 & 10 & -125 & -1 \\
\hline Büyükkütah & 503 & 320 & 247 & $-50,9$ & $-22,8$ & 124 & 211 & 282 & 158 & 71 & 485 & 716 & 631 & 146 & -85 \\
\hline Canpolat Paşa & 320 & 347 & 264 & $-17,5$ & $-23,9$ & & 161 & 210 & 210 & 49 & & 287 & 264 & 264 & -23 \\
\hline
\end{tabular}




\begin{tabular}{|c|c|c|c|c|c|c|c|c|c|c|c|c|c|c|c|}
\hline Cumhuriyet & 548 & 379 & 215 & $-60,8$ & $-43,3$ & & 129 & 147 & 147 & 18 & & 32 & 27 & 27 & -5 \\
\hline Çaylak & 404 & 408 & 284 & $-29,7$ & $-30,4$ & 137 & 145 & 201 & 64 & 56 & 20 & 50 & 47 & 27 & -3 \\
\hline Demirciler & 1184 & 1151 & 894 & $-24,5$ & $-22,3$ & 1450 & 372 & 484 & -966 & 112 & 120 & 53 & 56 & -64 & 3 \\
\hline Deveciler & 783 & 865 & 571 & $-27,1$ & $-34,0$ & 1842 & 335 & 369 & -1473 & 34 & 195 & 159 & 134 & -61 & -25 \\
\hline Doğan Güreş Paşa & 1754 & 1974 & 2523 & 43,8 & 27,8 & & 1097 & 1407 & 1407 & 310 & & 137 & 195 & 195 & 58 \\
\hline Ebulüle & 395 & 604 & 1264 & 220,0 & 109,3 & 156 & 632 & 881 & 725 & 249 & 30 & 75 & 157 & 127 & 82 \\
\hline Ekrem Çetin & 3713 & 6614 & 13880 & 273,8 & 109,9 & & 5327 & 7755 & 7755 & 2428 & & 504 & 855 & 855 & 351 \\
\hline Fatih Sultan Mehmet & 1300 & 1563 & 1624 & 24,9 & 3,9 & & 431 & 628 & 628 & 197 & & 29 & 75 & 75 & 46 \\
\hline Gaziler & 484 & 437 & 352 & $-27,3$ & $-19,5$ & & 179 & 225 & 225 & 46 & & 18 & 20 & 20 & 2 \\
\hline Hacı Gümüş & 223 & 0 & 152 & $-31,8$ & 0 & 55 & 77 & 92 & 37 & 15 & 3 & 4 & 1 & -2 & -3 \\
\hline Hacı İlyas & 199 & 0 & 127 & $-36,2$ & 0 & 30 & 56 & 79 & 49 & 23 & 4 & 9 & 9 & 5 & 0 \\
\hline Hakverdi & 527 & 540 & 359 & $-31,9$ & $-33,5$ & 149 & 230 & 246 & 97 & 16 & 66 & 107 & 111 & 45 & 4 \\
\hline Hasan Kamil Demirbaş & 1685 & 1374 & 955 & $-43,3$ & $-30,5$ & & 434 & 542 & 542 & 108 & & 49 & 48 & 48 & -1 \\
\hline Helvacioğlu & 1032 & 1590 & 2282 & 121,1 & 43,5 & 23 & 709 & 853 & 830 & 144 & 0 & 22 & 45 & 45 & 23 \\
\hline Hindioğlu & 536 & 389 & 320 & $-40,3$ & $-17,7$ & 144 & 162 & 193 & 49 & 31 & 12 & 38 & 52 & 40 & 14 \\
\hline Hürriyet & 1385 & 1364 & 999 & $-27,9$ & $-26,8$ & & 469 & 539 & 539 & 70 & & 88 & 99 & 99 & 11 \\
\hline İnnaplı Kütah & 529 & 428 & 310 & $-41,4$ & $-27,6$ & 125 & 204 & 257 & 132 & 53 & 142 & 268 & 262 & 120 & -6 \\
\hline İslambey & 393 & 483 & 335 & $-14,8$ & $-30,6$ & & 179 & 219 & 219 & 40 & & 42 & 57 & 57 & 15 \\
\hline İsmet Paşa & 4257 & 3991 & 3707 & $-12,9$ & $-7,1$ & & 1448 & 1729 & 1729 & 281 & & 334 & 385 & 385 & 51 \\
\hline İzzettin İyigün Paşa & 1267 & 1198 & 876 & $-30,9$ & $-26,9$ & & 477 & 527 & 527 & 50 & & 118 & 130 & 130 & 12 \\
\hline Kanuni Sultan Süleyman & 1885 & 1794 & 1537 & $-18,5$ & $-14,3$ & & 529 & 664 & 664 & 135 & & 128 & 113 & 113 & -15 \\
\hline Karaali & 670 & 693 & 477 & $-28,8$ & $-31,2$ & 179 & 238 & 313 & 134 & 75 & 8 & 29 & 37 & 29 & 8 \\
\hline Kartalbey & 1141 & 1097 & 1035 & $-9,3$ & $-5,7$ & & 441 & 521 & 521 & 80 & & 71 & 89 & 89 & 18 \\
\hline Kazım Karabekir & 1302 & 2312 & 5552 & 326,4 & 140,1 & & 2109 & 3170 & 3170 & 1061 & & 214 & 3465 & 3465 & 3251 \\
\hline Ketenciler & 559 & 413 & 305 & $-45,4$ & $-26,2$ & 104 & 168 & 188 & 84 & 20 & 22 & 46 & 133 & 111 & 87 \\
\hline Maraşal Fevzi Çakmak & 1637 & 1541 & 1219 & $-25,5$ & $-20,9$ & & 533 & 671 & 671 & 138 & & 73 & 98 & 98 & 25 \\
\hline Mehmet Rifat Kazancioğlu & 0 & 600 & 7190 & 0,0 & 1098,3 & & 2194 & 2799 & 2799 & 605 & & 596 & 754 & 754 & 158 \\
\hline Mehmet Sanlı & 0 & 3264 & 5221 & 0,0 & 60,0 & & 1563 & 1924 & 1924 & 361 & & 13 & 97 & 97 & 84 \\
\hline Mercidabık & 804 & 802 & 575 & $-28,5$ & $-28,3$ & & 318 & 376 & 376 & 58 & & 69 & 76 & 76 & 7 \\
\hline Meşetlik & 419 & 378 & 286 & $-31,7$ & $-24,3$ & 120 & 163 & 180 & 60 & 17 & 101 & 148 & 148 & 47 & 0 \\
\hline Mihali & 425 & 501 & 337 & $-20,7$ & $-32,7$ & 257 & 171 & 208 & -49 & 37 & 95 & 105 & 91 & -4 & -14 \\
\hline Muallim Rifat Bilge & 1110 & 1034 & 934 & $-15,9$ & $-9,7$ & & 332 & 429 & 429 & 97 & & 38 & 33 & 33 & -5 \\
\hline Mullahamit & 499 & 461 & 385 & $-22,8$ & $-16,5$ & 159 & 186 & 271 & 112 & 85 & 129 & 116 & 118 & -11 & 2 \\
\hline Mücahitler & 1031 & 1260 & 1314 & 27,4 & 4,3 & & 398 & 513 & 513 & 115 & & 28 & 47 & 47 & 19 \\
\hline Müslümanbey & 766 & 947 & 848 & 10,7 & $-10,5$ & & 329 & 384 & 384 & 55 & & 42 & 41 & 41 & -1 \\
\hline Nacaroğlu & 366 & 399 & 298 & $-18,6$ & $-25,3$ & 101 & 147 & 179 & 78 & 32 & 5 & 1 & 6 & 1 & 5 \\
\hline Namık Kemal & 1328 & 1387 & 997 & $-24,9$ & $-28,1$ & & 530 & 614 & 614 & 84 & & 50 & 64 & 64 & 14 \\
\hline Namık Ünler Paşa & 1151 & 1251 & 1137 & $-1,2$ & $-9,1$ & & 338 & 471 & 471 & 133 & & 34 & 48 & 48 & 14 \\
\hline Necmettin Erbakan & 0 & 0 & 3398 & 0,0 & 0 & & 1087 & 2337 & 2337 & 1250 & & 64 & 156 & 156 & 92 \\
\hline Nedim Ökmen & 1942 & 2023 & 1577 & $-18,8$ & $-22,0$ & & 679 & 866 & 866 & 187 & & 86 & 108 & 108 & 22 \\
\hline Nurettin & 273 & 0 & 153 & $-44,0$ & 0 & 80 & 87 & 155 & 75 & 68 & 10 & 5 & 32 & 22 & 27 \\
\hline Okçular & 668 & 682 & 535 & $-19,9$ & $-21,6$ & 190 & 222 & 281 & 91 & 59 & 4 & 26 & 18 & 14 & -8 \\
\hline Osman Gazi & 833 & 750 & 545 & $-34,6$ & $-27,3$ & & 281 & 326 & 326 & 45 & & 90 & 73 & 73 & -17 \\
\hline Oylum & 0 & 700 & 576 & 0,0 & $-17,7$ & & 258 & 332 & 332 & 74 & & 10 & 20 & 20 & 10 \\
\hline Öncüpınar & 2098 & 1510 & 1351 & $-35,6$ & $-10,5$ & & 434 & 601 & 601 & 167 & & 11 & 20 & 20 & 9 \\
\hline Polat Paşa & 1495 & 1454 & 1153 & $-22,9$ & $-20,7$ & & 471 & 629 & 629 & 158 & & 29 & 40 & 40 & 11 \\
\hline Saraç Mehmet Çavuş & 1408 & 1480 & 1282 & $-8,9$ & $-13,4$ & & 477 & 670 & 670 & 193 & & 46 & 85 & 85 & 39 \\
\hline Şehit Sakıp & 1233 & 1550 & 1096 & $-11,1$ & $-29,3$ & 335 & 626 & 649 & 314 & 23 & 101 & 267 & 272 & 171 & 5 \\
\hline Şehitler & 656 & 602 & 432 & $-34,1$ & $-28,2$ & & 258 & 271 & 271 & 13 & & 121 & 165 & 165 & 44 \\
\hline Şı Ah Abdullah & 1365 & 1539 & 1033 & $-24,3$ & $-32,9$ & 2713 & 474 & 576 & -2137 & 102 & 515 & 55 & 69 & -446 & 14 \\
\hline
\end{tabular}




\begin{tabular}{|c|c|c|c|c|c|c|c|c|c|c|c|c|c|c|c|}
\hline Şih Ahmet & 574 & 517 & 406 & $-29,3$ & $-21,5$ & & 155 & 218 & 218 & 63 & & 32 & 31 & 31 & -1 \\
\hline Şı Mehmet & 1205 & 1125 & 2073 & 72,0 & 84,3 & & 667 & 1017 & 1017 & 350 & & 92 & 133 & 133 & 41 \\
\hline Şıhlar & 238 & 276 & 189 & $-20,6$ & $-31,5$ & 206 & 104 & 138 & -68 & 34 & 30 & 14 & 9 & -21 & -5 \\
\hline Şörhabil & 495 & 0 & 718 & 45,1 & 0 & & 202 & 266 & 266 & 64 & & 15 & 50 & 50 & 35 \\
\hline Tabakhane & 383 & 333 & 264 & $-31,1$ & $-20,7$ & 60 & 138 & 172 & 112 & 34 & 10 & 30 & 45 & 35 & 15 \\
\hline Tekye & 641 & 430 & 172 & $-73,2$ & $-60,0$ & 239 & 190 & 206 & -33 & 16 & 570 & 416 & 413 & -157 & -3 \\
\hline Tırıklı & 412 & 441 & 213 & $-48,3$ & $-51,7$ & 297 & 164 & 194 & -103 & 30 & 15 & 34 & 13 & -2 & -21 \\
\hline Vaiz & 497 & 470 & 379 & $-23,7$ & $-19,4$ & 235 & 167 & 248 & 13 & 81 & 48 & 52 & 57 & 9 & 5 \\
\hline Yaşar Aktürk & 0 & 4146 & 4991 & 0,0 & 20,4 & & 1676 & 1758 & 1758 & 82 & & 219 & 289 & 289 & 70 \\
\hline Yavuz Sultan Selim & 825 & 973 & 908 & 10,1 & $-6,7$ & 149 & 461 & 669 & 520 & 208 & 235 & 418 & 363 & 128 & -55 \\
\hline Yedi Aralık & 1351 & 1195 & 954 & $-29,4$ & $-20,2$ & & 525 & 567 & 567 & 42 & & 383 & 336 & 336 & -47 \\
\hline Yeni & 747 & 536 & 403 & $-46,1$ & $-24,8$ & 156 & 219 & 241 & 85 & 22 & 25 & 50 & 51 & 26 & 1 \\
\hline Zeytinli & 666 & 643 & 474 & $-28,8$ & $-26,3$ & & 247 & 297 & 297 & 50 & & 24 & 29 & 29 & 5 \\
\hline
\end{tabular}

Kaynak: DİE, Genel Nüfus Sayımı (2000), TÜİK, Nüfus İstatistikleri (2010-2019); TÜİK, Konut ve İşyeri İstatistikleri $(1990,2015,2019)$

Kilis kent nüfusu 2000 yılı sonrasında farklı dinamiklerle şekillenerek dağılış göstermiştir. $\mathrm{Bu}$ süreçte kente yeni mahalleler eklenerek kentsel alan büyümüş ve nüfuslanmıştır. Dış mahallelerin yüzölçümleri 2019 dağılış haritasında (Şekil 7) görünenden daha büyük alanlara yayılmıştı. Ancak çalışmada ikamet edilen (meskûn) alanlar dikkate alınarak dış mahalleler sınırlandırılmıştır. Önceki dönemlerde de belirtildiği üzere bu dönemde de şehrin büyük nüfuslu mahalleleri dış mahaller olmuştur. İç mahallelerde ise hissedilir ölçüde nüfus kaybı yaşanmıştır. Bu durum iç mahallelerden dış mahallelere göçün bir göstergesidir. Özellikle bu değişim 2011 yılından sonra şekillenmiştir. Çünkü Kilis'e gelen Suriyeli sığınmacılar kentin iç mahallelerindeki konut alanlarını (eski evler/düşük kira bedelleri için) tercih etmişlerdir. Bu durumda iç mahallelerde oturan yerli nüfus dış mahallelerdeki yeni konut alanlarına doğru göç etmiştir. Bu durum kentte artan konut ihtiyacı, hızlı kentleşme ve alansal gelişmeyi zorunlu kılmıştır. İç mahallelerdeki sıkışık kent dokusu günümüz şartlarında ciddi trafik ve park alanı gibi sorunları da yarattığından dolayı bu mahallelerden daha geniş ve planlı mahallelere kayış başlamıştır.

Kentin iç mahallelerinde alansal gelişimin tamamlandığı ve nüfus taşıma kapasitesine ulaşıldığ 1 görülmektedir. Gelişimi sürdüren mahalleler ise kentin dış mahalleleridir. Kentin kuzeybatısında yer alan üniversite çevresi nüfusun artış gösterdiği bir alan haline gelmiştir. $\mathrm{Bu}$ alanda Mehmet Sanlı, Atatürk ve Ekrem Çetin Mahalleleri nüfusun yüksek olduğu alanlardır. Bu mahallelerde toplu konut alanları, stüdyo daireler ve öğrenci yurtlarının inşa edilmesi nüfusun aglomera olmasını sağlamıştır. Bu gelişim ile kentsel yayılım şehrin batısına doğru büyüme eğilimi gösterebilecektir. Kentin batısında yükseltisi fazla olmayan tepelik alanlar ve sırtlar bir eşik oluşturmasına rağmen büyüme toplu konut alanları planlamasıyla Tahtalı Köyüne doğru ilerleyebilecektir. Kentin kuzey kismında ise yine toplu konut alanları planlamasiyla kentsel büyüme Atatürk ve Mücahitler Mahallesinde devam edecektir. Ancak bahsedilen büyüme Resul Osman Dağı eteklerinde olacağından kent ortalama rakımı da yükselmiş olacaktır. Tabloda (4) her üç mahalledeki nüfus artışının yüksek seyretmesi kentin büyüme alanlarının olduğunu gösterir.

Kentin batısında yer alan Şı Mehmet Mahallesi yeni konut alanlarının inşasıyla gelişen bir mahalle olmuştur. Bu mahalle gelişimini Şeyh Mehmet Tepesine doğru sürdürmektedir. Bu tepede yer alan türbe ise halkın kutsallığına inandığı önemli bir noktadır. Muhtemelen bu nokta kentin sınırını meydana getirecektir.

Kentin güney kısmında yer alan Kilis Devlet Hastanesi ise Kazım Karabekir ve Ebulüle Mahallelerinde nüfus artışını sağlamıştır. Her iki mahalle de yeni konut alanlarının inşasıyla büyüyen alanlardır. Ebulüle Mahallesindeki nüfus artışı muhtemelen önümüzdeki yıllar daha da artı̧̧ gösterecektir. Kilis 7 Aralık Üniversitesi'nin Mercidabık Kampüsü ve yeni belediye binasının 
inşasıyla birlikte bu mahallede yapılaşma hızlanacak ve yeni konutlarla nüfus artış gösterecektir (Şekil 7 - Tablo 4).

Kentin en önemli gelişme aksı ise doğu kesimi olup Kilis-Gaziantep yolu ekseninde gelişim görülmektedir. Yaşar Aktürk, Albay İbrahim Karaoğlanoğlu ve Doğan Güreş Paşa Mahalleleri Eski Beşevler Semti olarak ifade edilmektedir. Bu alan 2000 yılı nüfus dağılış haritasında da önemli nüfus alanlarındandır. Hala gelişim sürdürerek kentin önemli nüfus yığılım bölgesini meydana getirmektedir. Yeni hastanenin inşası ise bu kesimi daha da büyütecek, özellikle Yaşar Aktürk Mahallesinde nüfus artış gösterecektir. Necmettin Erbakan ve Mehmet Rıfat Kazancioğlu Mahalleleri ise Yeni Beşevler Semti olarak ifade edilmekte ve kentin yeni konut alanlarını bulundurmaktadır. Bu alanda arsa bedellerinin yüksek oluşu ekonomik gelir seviyesi yüksek olan nüfusun yoğunlaşma alanını da meydana getirmektedir (Şekil 7 - Tablo 4). Bu mahallelerin gelişimi verimli tarım alanlarına doğru olması kentin gelişim yönüne yapılan eleştirilere de sebep olmaktadır. Kentin doğusundaki bu mahallelerin daimi konut sınırından sonra mevsimlik kullanılan bağ evleri başlar ve Kilis-Gaziantep asfaltı boyunca, eskiden köy olan Oylum Mahallesine kadar, arsa ücretlerinin yüksek olduğu sayfiye meskenleri görülür.

Kilis kenti tek merkezli (monocentric) bir yapı göstermektedir. Merkezi iş sahasının bulunduğu Büyükkütah, Tekye ve Canpolat Paşa Mahalleleri, resmi kurum ve bankaların da yer alması nedeniyle önem arz eder. Bu tarihi mahallelerin dar ve sıkışık karakterde oluşu merkezi iş sahasının tıkanmasına sebep olmaktadır. Bu nedenle geniş iş alanlarına ihtiyaç duyan mağazalar (mobilya, beyaz eşya, kurumsal marketler) Yeni Beşevler semtine doğru kayış göstermektedir. Bazı kamu kurumlarının da (Adliye, PTT, Emniyet Müdürlüğü gibi) bu semte yakın oluşu kentte yeni bir merkezi oluşturmaya başlamıştır. $\mathrm{Bu}$ durumda tek merkezli kent yapısı, çok merkezli (policentric) kent yapısına doğru evrilmektedir.

Nüfus dağılışındaki durumu desteklemek için mahalleler bazında konut ve işyeri sayılarındaki değişime de bakılabilir. Tablo (4) incelendiğinde nüfus artışı yüksek olan mahallelerde konut ve işyeri sayısının da hızlı arttı̆̆ görülmektedir. 1990-2019 yılı konut sayıs1 farklarında eksiye düşen rakamlar mahallelerin bölünüşünden (Bölük, Demirciler, Deveciler, Şıh Abdullah) kaynaklanmıştır. 2015-2019 konut farklarında ise iç mahallelerde (Hacı Gümüş, Cumhuriyet, Hahverdi, Hacı İlyas, Tekye, Yeni, Meşetlik, Ketenciler gibi) konut artış farklarının düşük kalışı mahallelerin büyüme kapasitelerinin de tamamlandığını ortaya koyar. Oysa yukarıda da bahsedilen hızlı gelişim gösteren mahallelerde (Ekrem Çetin, Kâzım Karabekir, Atatürk, Mehmet Rifat Kazancioğlu, Mehmet Sanlı, Necmettin Erbakan, Şıh Mehmet, Albay İbrahim Karaoğlanoğlu gibi) konut artışlarının yüksek olduğu görülmektedir.

İşyeri sayıları bakımından merkezi iş sahasının yer aldığı mahallelerde ve iç mahallelerde (Büyükkütah, Deveciler, Mıhali, Şıhlar gibi) iş yeri sayılarındaki azalışlar dikkati çeker. Kentin yeni gelişim alanları olarak ifade edilen mahallelerde (Kâzım Karabekir, Ekrem Çetin, Mehmet Rifat Kazancioğlu, Mehmet Sanlı, Necmettin Erbakan, Şıh Mehmet, Yaşar Aktürk, Ebulüle gibi) ise iş yeri sayılarında yüksek artışlar görülmektedir (Tablo 4). Kent içi ticaret alanlarının yer değiştirme hareketi iş yeri sayısı değişimi üzerinde etkili olmuştur. Özellikle iç mahallelerdeki azalmanın diğer bir sebebi ise sığınmacı nüfusun kayıt dışı olarak ticarethaneleri kiralamasından kaynaklanmaktadır.

\section{Nüfusun Cinsiyet ve Yaş Yapısı}

Bir yerin nüfus özellikleri içinde cinsiyet/yaş yapısının durumu nüfusun büyüklügü kadar önemli bir değişkendir. Bu yapının mevcut durumu ve gelişim süreci üzerinde doğal değişimin yanında, göçler de belirleyici olmaktadır. Sonuçta cinsiyet/yaş yapısı, toplumsal ve iktisadi duruma etki etmekte ve böylece coğrafi görünüm üzerinde, belirleyici değişkenlerden biri haline gelmektedir (Canpolat, 2019: 190). Bir bölgedeki nüfusun yaş ve cinsiyet yapıs1, demografik öneminin yanı sıra, sosyal ve ekonomik özellikler bakımından da büyük önem taşır (Koca, 2005). 
Belirli bir nüfus içerisindeki 100 veya 1000 kadın başına düşen erkek sayısı (Tümertekin ve Özgüç, 2011: 272) olarak tanımlanan cinsiyet oranının belirlenmesi ve bilinmesi bu açıdan önem arz etmektedir. Ayrıca bir nüfus grubundaki yaş yapısının da bilinmesi insanların ihtiyaçlarının, eğilimlerinin ve sosyal işlevlerinin belirlenmesi ve bu yönde uygulanacak politikaların oluşturulması açısından önem arz etmektedir (Işık, 1997).

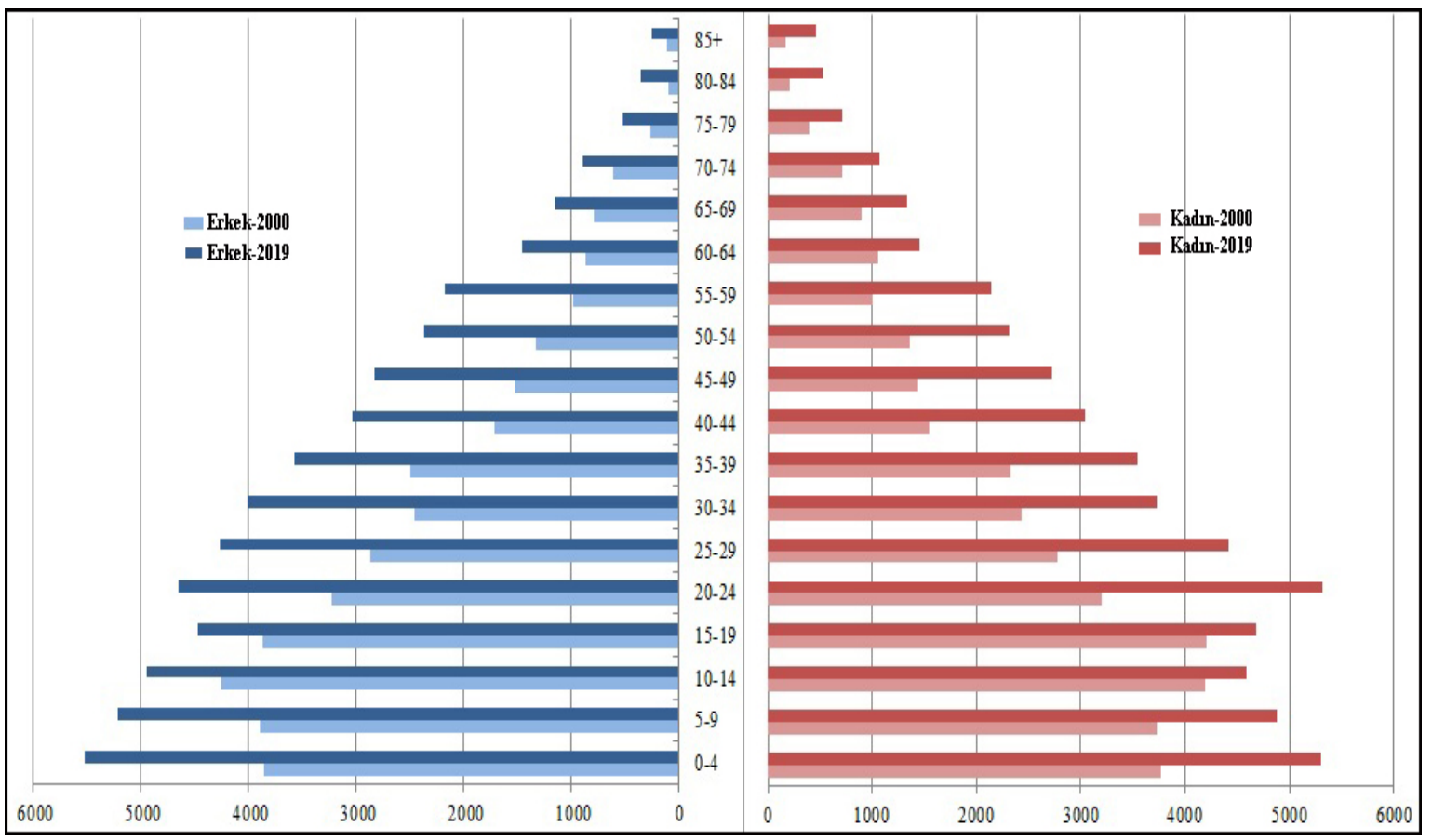

Şekil 8. Kilis Kent Nüfusu Yaş ve Cinsiyet Yapısı (2000 ve 2019)

Nüfusun dar aralıklı yaş grubuna ve cinsiyete göre hazırlanan nüfus piramitleri nüfustaki değişim ve gelişimi analiz etmek için kullanılan araçlardandır. Bir nüfus piramidi iyi okunursa o yerdeki nüfusun geçirmiş olduğu süreç ve hatta geleceği hakkında ön görülerde de bulunulabilir. Kentsel nüfusun gelişimi için 2000 ve 2019 yılları nüfusları grafiklere dökülerek nüfus piramidi meydana getirilmiştir. Aslında Kilis'in il olmazdan önceki 1990 nüfus verileriyle 2019 nüfus verileri piramitte verilmek istenmiştir. Ancak 1990 nüfus verilerinin bilinçli olarak fazla gösterilmesi doğru sonuçlar vermeyecekti. Bu nedenle 2000 ve 2019 nüfus verilerinden hareketle piramit oluşturulmuştur.

Kilis kenti nüfus piramidi analiz edildiğinde (Şekil 8) tüm yaş gruplarında 2000 nüfusuna göre 2019 nüfusunun yüksek olduğu görülmektedir. 2000 yılı nüfus grafiğinde tabanın 10-14 yaş grubundan itibaren daraldığı görülmektedir. Bu daralmanın sebebi özellikle kentsel nüfusta doğum oranlarındaki düşüşle açıklanabilir. Ancak 2019 yılı verilerinden hazırlanan nüfus grafiğinde ise taban kısmın tekrar genişlediği görülmektedir. Bu genişlemede etkili olan faktör kentteki sığınmacı nüfusun yoğunluğu sebebiyle kamu hizmetlerinde görevli (polis, asker, öğretmen, sağlik personeli vb.) genç nüfusun kentteki doğum oranlarına etki ettiği ifade edilebilir. Grafikte 2019 yılı 20-24, 25-29 yaş grubundaki genişlik bu tezi kanıtlar niteliktedir. Piramitte görülen diğer bir husus yaşli nüfus oranı 2000 yılına göre 2019 'da artış göstermiştir. Bu durumda etkili olan faktör ise ortalama yaşam süresinin yükselmesidir. Diğer bir husus ise cinsiyet oranlarıdır. Kilis kentinde cinsiyet oranlarının birbirine çok yakın olduğu şekil 8 üzerinde görülmektedir. 
Tablo 5: Kilis Kentinde Nüfusun Yaş Aralıkları ve Bağımlı Nüfus Oranı (2000-2019)

\begin{tabular}{cccccccccc}
\hline \multirow{2}{*}{ Yıllar } & \multirow{2}{*}{ Toplam } & \multicolumn{2}{c}{ 0-14 Yaş } & \multicolumn{2}{c}{ 15-64 Yaş } & \multicolumn{2}{c}{ 65 + Yaş } & \multirow{2}{*}{$\begin{array}{c}\text { Bağımlı Nüfus } \\
\text { Oranı \% }\end{array}$} \\
\cline { 3 - 7 } & Nüfus & \% & Nüfus & \% & Nüfus & \% & \\
\hline 2000 & 70620 & 23681 & 34 & 42652 & 60 & 4287 & 6 & 65 \\
\hline 2019 & 103883 & 30441 & 29 & 66151 & 64 & 7291 & 7 & 52 \\
\hline
\end{tabular}

Kaynak: DiE, Genel Nüfus Sayımı (2000); TÜIK, ADNKS Nüfus İstatistikleri (2019)

Birçok ülkede 15-64 yaş grubu içerisinde yer alan nüfus aktif nüfus, faal nüfus veya çalışma çağındaki nüfus olarak kabul edilmektedir. Bu nüfus grubunun dişında kalan 0-14 yaş grubu ve 65 yaş üstü nüfus ise pasif nüfus, bağımlı nüfus veya faal olmayan nüfus olarak ifade edilir. Aktif ve pasif nüfus oranları bir yerleşmedeki toplam nüfusa, nüfus artışına, doğurganlık oranına, kentleşme hızına, göçlere ve eğitim seviyesine göre değişkenlik gösterir. Kilis kent nüfusunda 2000 ve 2019 yılı nüfusu geniş aralıklı olarak gruplandırıldığında; 0-14 yaş grubu oranının 2019 yılında 2000 yılı nüfus oranına göre \%34'ten \%29'a gerilediği görülmektedir. 2019 yılı nüfus verilerinde doğum sayılarındaki artışa rağmen 15-64 yaş grubu nüfusun göçlerle kentte artış göstermesi oransal olarak 0-14 yaş grubundaki düşüşü meydana getirmiştir. 15-64 yaş grubunda 2019 yılı oranı 2000 yılı nüfus oranına göre \%60'tan \%64'e yükselmiştir. Bu yaş grubundaki oransal artış yukarıda da bahsedilen kentteki artan kamu görevlileri etkisiyle gerçekleşmiştir. Yaşlı nüfus payının 2019 yılında 2000 yılına göre \%6'dan \%7'ye yükselmesi ortalama yaşam süresinin uzamasıyla açıklanabilir. Bağımlı nüfus oranları hesaplandığında 2000 yılı yaş bağımlılık oranı \%65 iken 2019 yılında \%52'ye gerilemiştir. Dolayısıyla bu düşüşte etkili olan faktör 15-64 yaş nüfusun kent nüfusu içerisindeki artışıdır (Tablo 5).

\section{Nüfusun Sosyo-Ekonomik Yapısı}

Kilis uzun tarihi boyunca ticaret fonksiyonu ile varlığını sürdürmüş bir kenttir. Ancak bu fonksiyonun zaman zaman kaybedilmesi kentte sosyo-ekonomik anlamda gerilemelere sebep olmuştur. Kentin bugün ülke içi ulaşımda sapa kalması ve ulaşım bağlantısının sadece Gaziantep ile olması kent hareketliliğini etkilemiştir. Kilis için önemli olan Öncüpınar Sınır Kapısı'nın da Suriye iç savaşı sebebiyle zaman zaman kapanması kentteki hareketliliği büyük ölçüde azaltmıştır. Nüfusu 100 bini yeni așmış bir kent olarak Kilis kentinin etki sahası da bu bağlamda dar kalmaktadır. Kent merkezi, merkez ilçe hariç diğer 3 ilçeyi (Elbeyli, Musabeyli, Polateli) etki sahasına almada yetersiz kalmaktadır. Özellikle Elbeyli ilçesi Gaziantep'in etki sahası içerisinde kalmaktadır. Musabeyli ilçesi de bağlantı yolunun bulunması sebebiyle Gaziantep etki sahasından etkilenmektedir.

Hizmet sektörünün ağırlıklı olduğu Kilis’te sosyal güvenlik kapsamında aktif çalışan kişi sayısı toplamı 28.896 olup, bunun 17.176's1 4/a (SSK'l1lar), 5.775'i 4/b (tarımda çalışanlar da dâhil olmak üzere Bağ-Kur'lular), 6.035'i ise 4/c kapsamında çalışanlardır (memurlar). İlin ekonomik faaliyet olarak hangi sektörlerde yoğunlaştığı ve istihdam yarattığı konusunda önemli ipuçları veren 4/a kapsamındaki aktif sigortalılar içerisinde yer alan 15.395 zorunlu sigortalı (geri kalan zorunlu sigortalılar 1.781 kişi olup çırak, tarım, kısmi süreli ve yurtdışı topluluk sigortalılarından oluşmaktadır) yer almaktadır. En çok istihdam sağlayan sektör, 3.275 kişiyle "Bina ve Çevre Düzenleme Faaliyetleri" olup, onu 2.238 kișiyle "Eğitim" ve 1.610 kișiyle de "Bina Dıșı Yapıların İnşaatı" izlemektedir. En çok işyeri sayısı ise 239 işyeriyle "Perakende Ticaret" sektörü olurken, bu faaliyet alanında istihdam edilen sigortalı sayss ise 747 olup, siralamada altınc1 sirada yer almaktadır. Sosyal güvenlik kapsamında aktif çalışanların İl nüfusuna oranı $\% 23,31$ ile $\% 28,02$ olan Türkiye ortalamasının oldukça altında gerçekleşmiştir. İlde işgücüne katılım oranının düşük çıkmasında kayıt dışılı̆̆ın da etki si olduğu düşünülmektedir. Özellikle Suriyeli sığınmacıların da etkisiyle kayıt dış1ık artış göstermiştir (İpekyolu Kalkınma Ajansı, 2018). 
Tablo 6: Kilis Kentinde Nüfusun Eğitim Kademelerine ve Mahallelere Bölünüşü (2010-2018)

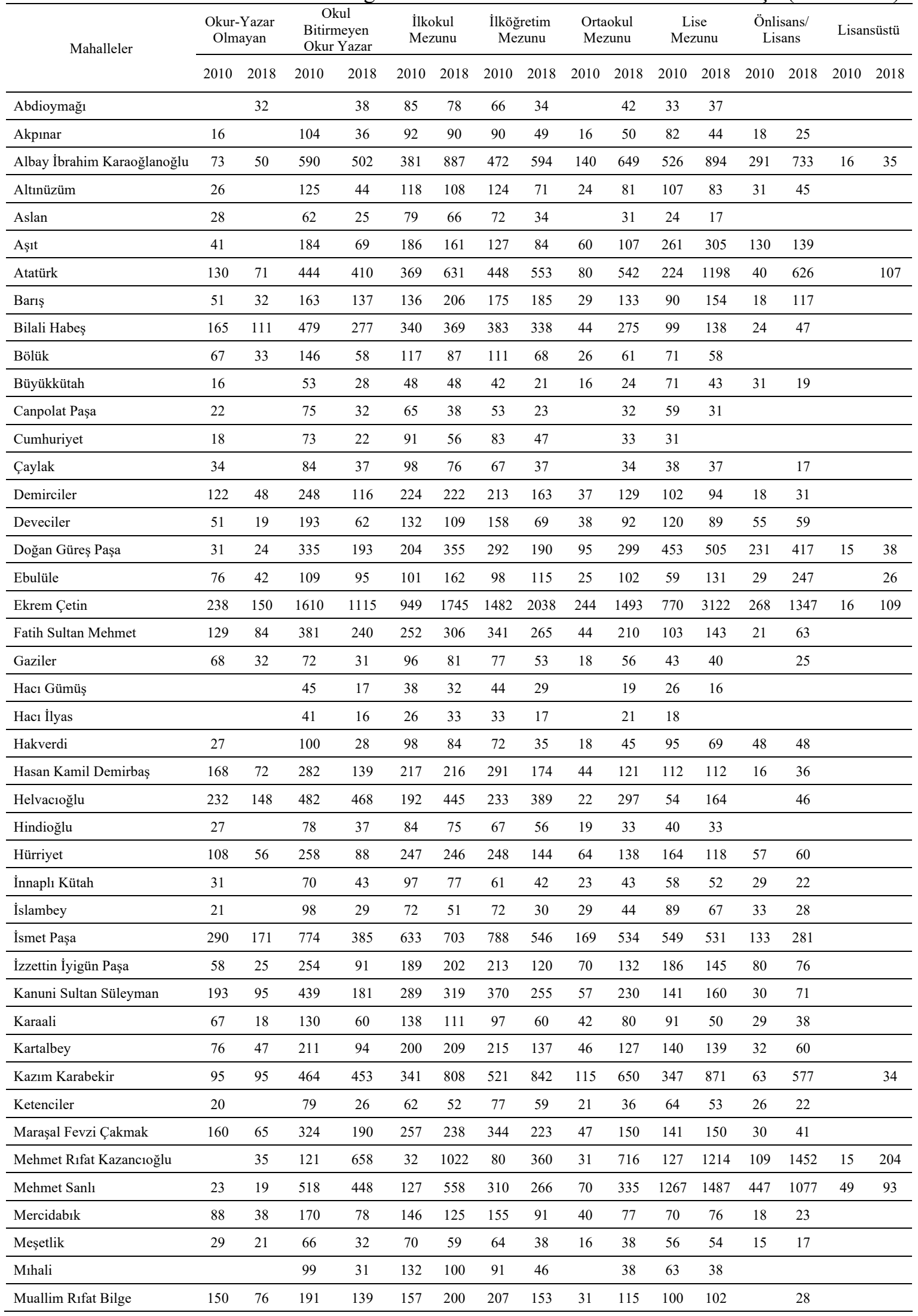




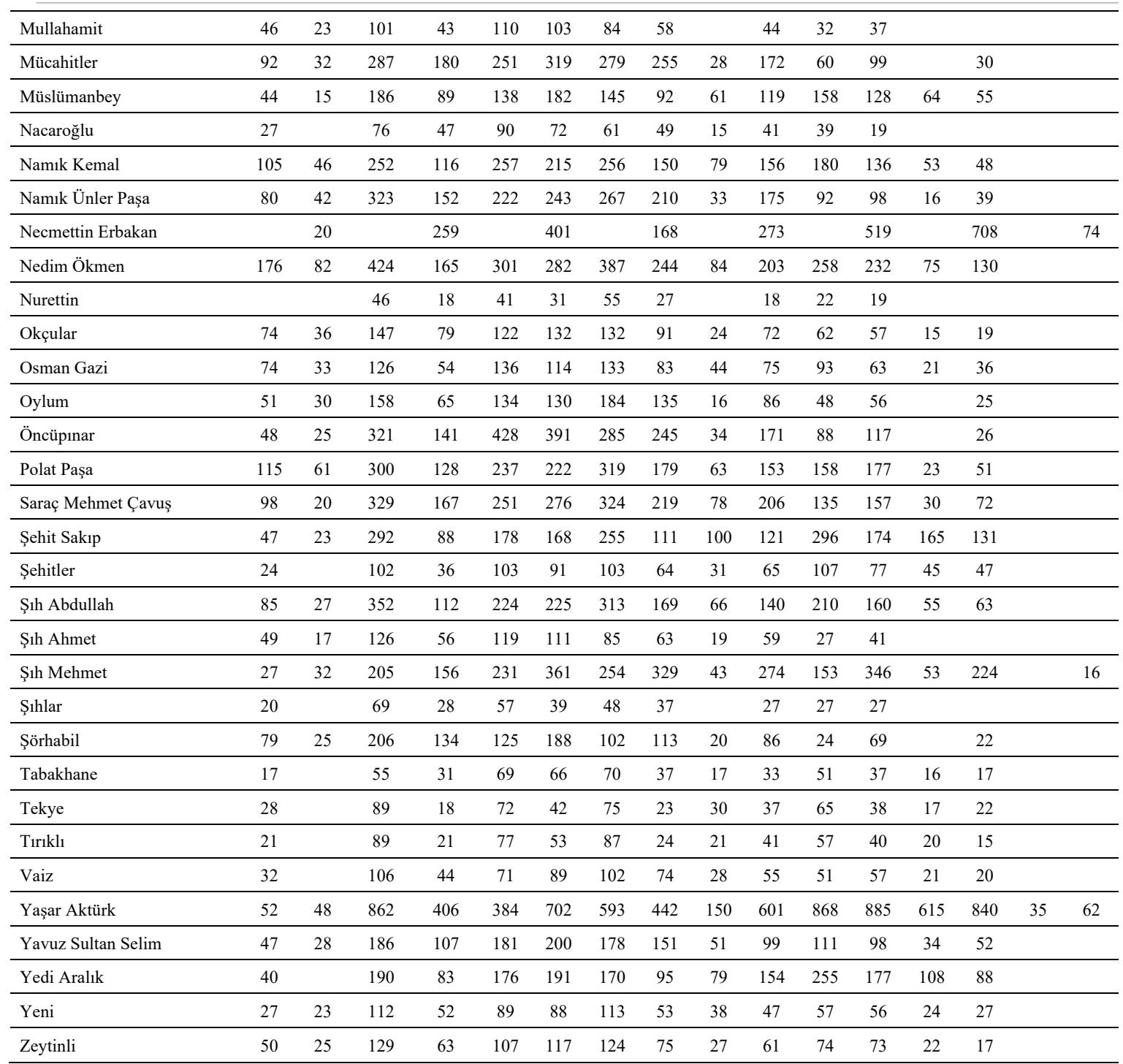

Kaynak: TÜİK, Eğitim İstatistikleri (2010-2018)

Kent nüfusunun eğitim durumuna bakıldığında 2018 yılı toplam nüfusun \% 2,8'i okuryazar olmayan nüfus durumundadır. Bu oranın büyük çoğunluğunu yaşlı nüfus meydana getirmektedir. Okuryazar ama bir okul bitirmeyenlerin oranı \%12; ilkokul mezunları oranı $\% 20,5$; ilköğretim mezun oran1 $\% 15$; ortaokul mezun oran1 $\% 14$; lise mezunları $\% 21$; ön lisans veya lisans mezunları oranı ise \%12,5'tir. Özellikle lise ve üniversite mezun oranlarına bakıldığında eğitim seviyesinin yüksek olmadığı görülmektedir. Eğitim kademelerine göre eğitim durumu mahalleler bazında analiz edildiğinde kentin iç mahalleleri ile dıș mahalleleri arasındaki farklılık dikkati çekmektedir. Abdioymağı, Aslan, Bölük, Canpolat Paşa, Cumhuriyet, Hacı Gümüş, Hacı İlyas, Hindioğlu, Mihali, Mullahamit, Nacaroğlu, Nurettin, Şıh Ahmet ve Şıhlar Mahallelerinde eğitim seviyelerinin düşük kaldığı görülmektedir. Oysa kentin gelişim gösterdiği dış mahallelerde eğitim seviyesinin de yüksek olduğu görülmektedir. Albay İbrahim Karaoğlanoğlu, Atatürk, Doğan Güreş Paşa, Ekrem Çetin, Kazım Karabekir, Mehmet Rıfat Kazancıoğlu, Mehmet Sanlı, Necmettin Erbakan ve Yaşar Aktürk Mahallelerinde eğitim seviyelerinin yüksekliği görülmektedir. Lisansüstü eğitim basamağından mezun olan nüfus ise belli mahallelerde yoğunluk göstermiştir. Albay İbrahim Karaoğlanoğlu, Atatürk, Doğan Güreş Paşa, Ebulüle, Ekrem Çetin, Kazım Karabekir, Mehmet Rifat Kazancioğlu, Mehmet Sanlı, Necmettin Erbakan, Şı Mehmet ve Yaşar Aktürk Mahallelerinde lisansüstü eğitim mezunları görülmektedir. Özellikle Atatürk ve Mehmet Sanlı 
Mahallelerinde üniversite lojmanlarının yer alması akademik personelden dolayı sayıları yükseltmiştir. Eski Beşevler ve Yeni Beşevler semtlerinde ise sosyo-ekonomik seviyenin yüksek oluşu eğitim seviyesi yüksek nüfusun yoğunlaşmasına sebep olmuştur (Tablo 6).

2007 y1lında Kilis 7 Aralık Üniversitesi'nin kurulmasıyla birlikte kent eğitim seviyesinde artışlar yaşanmıştır. 2008-2009 eğitim öğretim döneminde 2170 olan öğrenci sayısı 2018-2019 eğitim öğretim döneminde toplam 8833 olmuştur. Bu toplam sayısının 2696'sı ön lisans, 5771'i lisans ve 366'sı lisansüstü öğrenci statüsündedir. Toplam akademik personel sayısı ise 2019 yılında 374 kişiye ulaşmıştır (YÖK, 2019).

Kilis'te 2019 yılında toplam 34 bin çağ nüfus vardır. Bu çağ nüfusun \%93'ü okullaşan, \%7'si ise okullaşmayan nüfustur. Eğitim kademelerine göre okul öncesinde okullaşma \%96; ilkokulda \%98; ortaokulda $\% 98$ ve lisede $\% 87$ oranındadır. Ancak Kilis eğitim sisteminde toplam 37.500 Suriyeli sığınmacı çağ nüfus vardır. Bu nüfusun da ancak \%59'u okullaşabilmiştir. Eğitim kademelerine göre Suriyeli çocuklarda okullaşma oranı okul öncesi eğitiminde \%50,7; ilkokulda $\% 45$; ortaokulda \%43; lisede ise $\% 32$ 'dir. Rakamlarda görüldügüü üzere Suriyeli sığınmacı nüfusta okullaşma oranı düşük kalmaktadır. Şubelerde yer alan öğrenci sayılarının da Kilis'te yüksek olduğu görülmektedir. Okulöncesinde 22,5; ilkokulda 45; ortaokulda 43 ve lisede 32 öğrenci ortalaması görülmektedir. Ortalamanın yüksek oluşunun sebebi Suriyeli sığınmacı nüfusun da kentteki okullarda eğitim sürecine dâhil edilmesi sonucudur (Burak, Uzun ve Amaç, 2019).

Tablo 7: Kilis Kentinde Medeni Durum (2008-2019)

\begin{tabular}{|c|c|c|c|c|c|c|c|c|}
\hline \multirow{2}{*}{ Yillar } & \multicolumn{2}{|c|}{ Evli } & \multicolumn{2}{|c|}{ Hiç Evlenmedi } & \multicolumn{2}{|c|}{ Boşandı } & \multicolumn{2}{|c|}{ Eşi Öldü } \\
\hline & Erkek & Kadın & Erkek & Kadın & Erkek & Kadın & Erkek & Kadın \\
\hline 2008 & 20723 & 20833 & 9770 & 7867 & 449 & 741 & 486 & 3385 \\
\hline 2009 & 20981 & 21184 & 10145 & 7816 & 441 & 753 & 488 & 3431 \\
\hline 2010 & 21438 & 21623 & 9982 & 8080 & 452 & 774 & 499 & 3502 \\
\hline 2011 & 21834 & 21929 & 10943 & 8124 & 480 & 789 & 494 & 3537 \\
\hline 2012 & 22170 & 22280 & 11142 & 7777 & 520 & 818 & 504 & 3547 \\
\hline 2013 & 22469 & 22450 & 11716 & 9626 & 538 & 855 & 531 & 3603 \\
\hline 2014 & 22898 & 22798 & 11900 & 9729 & 575 & 888 & 528 & 3648 \\
\hline 2015 & 23465 & 23169 & 12485 & 10439 & 618 & 950 & 556 & 3723 \\
\hline 2016 & 23814 & 23260 & 12521 & 10417 & 656 & 974 & 568 & 3784 \\
\hline 2017 & 25343 & 24126 & 13740 & 10614 & 831 & 1052 & 587 & 3887 \\
\hline 2018 & 26164 & 24929 & 14026 & 10808 & 886 & 1107 & 564 & 3916 \\
\hline 2019 & 26465 & 25440 & 13877 & 10894 & 909 & 1172 & 588 & 3964 \\
\hline $\begin{array}{c}\text { 2008-2010 } \\
\text { Değișim \% }\end{array}$ & 28 & 22 & 42 & 38 & 102 & 58 & 21 & 17 \\
\hline
\end{tabular}

Kaynak: TÜIK, Medeni Durum İstatistikleri $(2008,2019)$

Medeni durum verileri incelendiğinde yıllar içerisinde değişimlerin yaşandığ görülmektedir. Evli nüfus sayılarında 2013 yılına kadar kadın evli nüfus fazlalığı varken, bu tarihten sonra erkek evli nüfusta fazlalıklar görülmektedir. Bu durumun sebebi Suriye iç savaşının yansımaları sebebiyle Kilis'e çok sayıda ilave güvenlik görevlisi ve kamu görevlisinin gelmesindendir. Bu kişilerin genellikle geçici görev ile Kilis'te bulunmaları sebebiyle ailelerini getirmemeleri kentte erkek evli nüfus sayısının artışına sebep olmuştur. Hiç evlenmeyen nüfus kentteki nüfusun artışına paralel olarak hem erkek hem de kadın nüfusta artış göstermektedir. Medeni durumda görülen boşanan çift sayıları ise Türkiye genelinde olduğu gibi Kilis kentinde de önemli bir toplumsal problemdir. Boşanan nüfus sayısı 2008 yılında 1190 iken 2019 yılında 2081 kişiye yükselmiştir (Tablo 7). Bu rakam nüfus artış hızıyla karşılaştırıldığında çok yüksek kalmaktadır. Boşanma sayılarındaki bu artışın Suriyeli sığınmacıların gelmesiyle hızlandı̆̆ını savunan kesimlerde vardır. Ancak bu durumu ispat edecek bir veri bulunmamaktadır. Boşanan çiftler arasında kadın nüfus fazlalığı erkek nüfusun boşandıktan sonra diğer şehirlere doğru göç 
etmesiyle açıklanabilir. Eşi ölen nüfus içinde ise kadınlarda ortalama yaşam süresinin uzunluğunun etkisiyle daha yüksektir.

Kentin sağlık fonksiyonlarına bakıldığında, 2007 yılında Kilis Devlet Hastanesi’nin yeni hizmet binasına taşınmasıyla 25 poliklinik, 131 doktor ve 321 yatak kapasitesi ile hizmet vermektedir. Ayrıca kentte 10 aile sağlığı merkezi, 2 ağız ve diş sağlığı merkezi ile 1 özel tıp merkezi bulunmaktadır. Kilis'te sığınmacı nüfusun da 112.192 kişi olması kentte sağlık sistemleri üzerindeki yı̆̆ılmayı meydana getirmektedir (www.kilis.gov.tr, 2020). Bu nedenle özellikle Kilis yerli nüfusu sağlık ihtiyaçlarını Gaziantep'teki hastanelerde gidermektedir.

\section{Sonuç}

Kentlerin fonksiyonel özellikleri nüfus taşıma kapasitesinde ve demografik yapıda etkili olan önemli bir faktördür. Kilis'in gelişim ve nüfuslanma sürecinde fiziki faktörlerden ziyade beşeri faktörler ön planda olmuştur. Tarihi süreç olarak eski bir kent olan Kilis'te nüfus ve gelişim ticari fonksiyonun değişimine bağlı tepkiler vermiştir. Cumhuriyet öncesi dönemde Halep ile olan sıkı ticari ilişkiler sebebiyle canlı kalmış, ancak Türkiye-Suriye sınırının belirlenmesiyle Kilis bağlantı fonksiyonunu kaybetmiştir. Eskiden "istasyon şehri” olarak nitelendirilebilecek kent ulaşım ve ticari fonksiyonunu kaybederek göç vermeye başlamıştır. 1960 ve 1970'li yıllarda ise yeniden ticari fonksiyonun belirmesi (sınır ticareti) kentte hareketliliğe sebep olmuştur. Kentteki diğer önemli gelişim ise 1995 yılında il statüsüne geçişle Kilis kenti il merkezi haline gelmiştir. İdari fonksiyondaki bu gelişme kentte nüfus artışına da sebep olmuştur. 2011 yılından itibaren Suriye iç savaşından kaçarak gelen sığınmacı nüfus ile birlikte kentte nüfus yığılımı meydana gelmiştir. Ancak çalışmada Suriyeli sığınmacı nüfusun mekânsal analizi yapılmamış, sadece yerli nüfus verileri dikkate alınarak değerlendirmeler yapılmıştır. Son yıllarda nüfus artış hızında pozitif yönlü bir hareketlilik görünse de bu gelişim kentte artan geçici kamu görevlileri etkisiyledir. Aslında Kilis uzun yıllardan beri durağan nüfus gelişimi sergilemektedir. Bu durağanlığın sebebi ise şunlardır:

- Kilis ulaşım fonksiyonunu büyük ölçüde kaybetmiş bir kenttir. Ülke içi bağlantısını sadece Gaziantep ile sağlayabilmektedir. Dolayısıyla konumu gereği yalıtılmış bir kenttir. Öncüpınar sınır kapısının ise zaman zaman siyasi sebeplerle kapalı olması ulaşım fonksiyonunu etkilemiştir. Ulaşım fonksiyonu için projeler arasında da bulunan Gaziantepİskenderun liman yolunun Kilis üzerinden geçirilmesi önemli bir gelişme olacaktır.

- Ekonomik faaliyetin yetersiz oluşu nüfus tutma kapasitesinin düşük olmasına sebep olmaktadır. Kent hizmet ağırlıklı bir yapıdadır. Organize Sanayi Bölgesi olmasına rağmen yeterli üretim kapasitesine ulaşılamamıştır. Ancak proje halinde olan Polateli Organize Sanayi Bölgesinin hayata geçmesiyle kent nüfus tutma kapasitesi artış gösterebilecektir.

- Kilis merkezi yer olma açısından zayıf ve etki sahasının dar olması sebebiyle idari açıdan bağlı bulunan yerleşmelerde etkisi sınırlıdır. Yanında büyük şehir ve etki sahası yüksek Gaziantep'in bulunması Kilis etki sahasını hayli daraltmıştır.

- 2011 yılından itibaren gelen sığınmacı nüfusun kentte ucuz iş gücü yaratması sonucu yerli nüfus diğer şehirlere doğru göç eğilimindedir. Ancak bu etki Kilis’teki artan kamu görevlisi sayısının fazlalığı sebebiyle verilerde görülememektedir. Yapılan alan araştırmasında göç verildiği ve göç etme eğilimlerinin arttı̆̆ bilgisine ulaşılmıştır.

- Kilis 2016 yılında roket saldırıları sebebiyle önemli güvenlik problemleri yaşamış bir kenttir. Bu güvenlik sorunu kentten göç eğilimini artırmıştır.

Kilis kenti son yıllarda sığınmacı nüfusun da etkisiyle önemli kentsel büyüme sağlamış bir yerleşmedir. Yeni kurulan mahallelere özellikle kentin iç mahallelerinden bir hareketlilik başlamıştır. İç mahallelerde sığınmacı nüfus yoğunlaşırken dış mahallelerde yerli nüfus yoğunluk göstermektedir. Artan konut ihtiyacı sebebiyle kentte inşaat sektörü son yıllarda canlanmıştır. 
Kentsel yayılım kuzeybat1, batı ve doğu yönüne doğru gelişim göstermektedir. $\mathrm{Bu}$ gelişimde üniversite, hastane ve Kilis-Gaziantep karayolu etkili olmuştur. Yeni devlet hastanesinin ise şehrin kuzeydoğusunda yeni yapılaşmayı başlatacağı tahmin edilmektedir. Kentin güney kısma doğru gelişimi eleştirilere sebep olmaktadır. Verimli tarım arazilerinin yer alması (fıstıklık, zeytinlik ve bağ alanları) güney kısma doğru gelişimi yavaşlatmıştır. Dolayısıyla çevre yolu şehrin bugün psikolojik sınırıdır.

\section{Kaynakça}

Akbal, F. (1951). 1831 Tarihinde Osmanlı İmparatorluğu'nda idari taksimat ve nüfus. Belleten, $X V(60), 617-628$.

Burak, D. Uzun, H. Amaç, Z. (2019). Kilis’teki geçici koruma altındaki Suriyeli çocukların eğitim durumlarının incelenmesi. V. International Congress on Social and Education Sciences (INCSES-2019).

Canpolat, F.A. (2019). Tunceli kentinin nüfus özellikleri. Uluslararası Bilimsel Araştırmalar Dergisi, 4(2), 183-200. https://doi.org/10.21733/ibad.537457

Doğanay, H. (1997). Türkiye beşeri coğrafyası. Milli Eğitim Bakanlığı Yayınları, Yayın No:2982, Bilim ve Kültür Eserleri Dizisi: 877, Eğitim Dizisi:10, Milli Eğitim Basımevi.

Doğanay, H. Orhan, F. (2014). Artvin ilinde nüfusun başlıca özellikleri. Doğu Coğrafya Dergisi, 19(31), 1-22. https://doi.org/10.17295/dcd.98734

Ehrlich, P. Anne H. (1990). The population explosion. Hutchinson. ISBN 0091745519.

Göney, S. (1977). Şehir coğrafyast. İstanbul Üniv. Edeb. Fak. Yay. No: 2274 Coğrafya Enstitüsü Yayın No: 91.

Gül, E. Çevik, B. (2015). 2013 verileriyle Türkiye'de illerin gelişmişlik düzeyi araştırması. Türkiye İşBankası. https://ekonomi.isbank.com.tr/ContentManagement/Documents/ar_07_2015.pdf

Gümüşçü, O. (2001). XVI. Yüzyıl Larende (Karaman) kazasında yerleşme ve nüfus. Türk Tarih Kurumu Yayınları.

Güzelbey, C. C. (1992). Gaziantep’ten kesitler. Arsan Yayını.

Işık, Ş. (1997). Güneydoğu Anadolu bölgesinde nüfusun miktarı ve yapısal özellikleri. Ege Coğrafya Dergisi, 9, 283-311.

İncili, Ö.F. (2013). XIX. Yüzyılda Kilis şehrinin coğrafi özellikleri. [Yayımlanmamış yüksek lisans tezi], Frrat Üniversitesi Sosyal Bilimler Enstitüsü.

İpekyolu Kalkınma Ajansı. (2018). Kilis Ekonomi Strateji Belgesi. ika.org.tr. https://www.ika.org.tr/upload/yayinlar/KILIS-EKONOMI-STRATEJI-BELGESI735282.pdf

Kesici, Ö. (1992). Kilis yöresinin beşeri ve ekonomik coğrafyası. [Yayımlanmamış doktora tezi], Atatürk Üniversitesi Sosyal Bilimler Enstitüsü.

Koca, H. (2005). Kuruluşu-gelişmesi ve fonksiyonel özellikleri yönünden Dörtyol şehri. Aktif Yayınevi.

Konyalı, İ. H. (1968). Abideleri ve kitabeleri ile Kilis tarihi. Fatih Matbaası.

Kökten, İ. K. (1952). Anadolu'da prehistorik yerleşme yerlerinin dağıllışı üzerine bir araştırma. Ankara Üniversitesi Dil ve Tarih-Coğrafya Fakültesi Dergisi, 10(3-4), 167-188. https://doi.org/10.1501/dtcfder_0000000970 
Özgür, E. M. (1998). Türkiye nüfus coğrafyası. GMC Basım Yayın.

Özgür, E.M. (2016). Bir alt alan olarak nüfus coğrafyasının geçmişi, bugünü ve geleceği. Ege Coğrafya Dergisi, 25(1), 1-36.

Rogers, A., Castree, N. ve Kitchin, R. (2013). Population geography. A Dictionary of Human Geography. Oxford University Press. ISBN 9780199599868. https://doi.org/10.1093/acref/9780199599868.001.0001

Tandoğan, A. (1998). Demografik temel kavramlar ve Türkiye nüfusu. Eser Ofset Matbaacıllk.

Tanoğlu, A. (1969). Nüfus ve yerleşme. İstanbul Üniversitesi Yayınları No: 1183, Edebiyat Fakültesi Coğrafya Enstitüsü Yayınları No:45.

Tümertekin, E. Özgüç, N. (2011). Beşeri coğrafya, insan-kültür-mekân. İstanbul: Çantay Kitabevi.

DİE (TÜIKK). (1927-2000). Genel nüfus sayımları. Erişim Tarihi 10.04.2020: (https://biruni.tuik.gov.tr/nufusmenuapp/menu.zul)

DİE (TÜIK). (2002). 2000 genel nüfus sayımı: nüfusun sosyal ve ekonomik nitelikleri: Il/Kilis. T.C. Başbakanlık Devlet İstatistik Enstitüsü.

TÜİK. (2018). Doğum istatistikleri. Erişim Tarihi 11.04.2020: (https://biruni.tuik.gov.tr/medas/?kn=113\&locale=tr)

TÜIKK. (2018). Ölüm istatistikleri. Erişim Tarihi 09.04.2020: (https://biruni.tuik.gov.tr/medas/?kn=114\&locale=tr)

TÜİK. (2010-2018). Eğitim istatistikleri. (TÜİK’ten veri talebi)

TÜIKK. (2007-2019). Nüfus istatistikleri. Erişim Tarihi 05.04.2020: (https://biruni.tuik.gov.tr/medas/?kn=95\&locale=tr)

TÜIKK. (2008-2019). Medeni durum istatistikleri. Erişim Tarihi 12.04.2020: (https://biruni.tuik.gov.tr/medas/?kn=95\&locale=tr).

TÜİK. (2015-2019). Konut ve iş yeri istatistikleri. (TÜİK'ten veri talebi)

Y1llık Hazırlama Komitesi. (1998). Cumhuriyet'in 75. Yllında Kilis. Önder Matbaacılık.

YÖK. (2019). Yüksek öğretim bilgi yönetim sistemi. Erişim Tarihi 20.04.2020: (https://istatistik.yok.gov.tr/)

www.kilis.gov.tr/saglik (Erişim Tarihi: 11.04.2020) 